OPEN ACCESS

Edited by:

Télesphore Sime-Ngando, Centre National de la Recherche

Scientifique, France

Reviewed by:

Ludwig Jardillier,

Université Paris-Sud, France

Pradeep Ram Angia Sriram, Centre National de la Recherche

Scientifique, France

*Correspondence:

Hélène Montanie

helene.montanie@univ-Ir.fr

Specialty section: This article was submitted to

Aquatic Microbiology,

a section of the journa

Frontiers in Microbiology

Received: 03 September 2015 Accepted: 19 October 2015 Published: 10 November 2015

Citation: Montanié H, De Crignis MG and Lavaud J (2015) Viral Impact on Prokaryotic and Microalgal Activities in the Microphytobenthic Biofilm of an Intertidal Mudflat (French Atlantic Coast). Front. Microbiol. 6:1214. doi: 10.3389/fmicb.2015.01214

\section{Viral Impact on Prokaryotic and Microalgal Activities in the Microphytobenthic Biofilm of an Intertidal Mudflat (French Atlantic Coast)}

\author{
Hélène Montanié *, Margot G. De Crignis and Johann Lavaud \\ UMRi 7266 ULR- Centre National de la Recherche Scientifique, LIENSs, Institut du Littoral et de l'Environnement, Université \\ de La Rochelle, La Rochelle, France
}

This is the first report on viriobenthos activity within the microbial biofilm located at the top-surface of the intertidal mudflat during emersion in Marennes-Oléron Bay (France). By combining in situ and ex situ approaches, the viral production (VP) was linked to the dynamics of prokaryotes and microphytobenthos (MPB). VP averaged 2-4 $\times 10^{8}$ viruses $\mathrm{ml}^{-1} \mathrm{~h}^{-1}$. VP correlated positively with the Virus to Prokaryote Ratio, and both were correlated negatively with the water content. The virus-induced mortality of prokaryotes was lower in winter than in summer (6.8 vs. $39.7 \%$ of the production) and the C-shunting may supply $2-12 \%$ of their Carbon Demand, respectively. VP accounted for $79 \%$ of loss in Prokaryotes but the response was delayed compared to the increase in VP suggesting a simultaneous release of viruses of MPB origin. This hypothesis is supported by capsid-sizing of virions by transmission electronic microscopy and bioassays. Harvesting and ex situ maintenance of top-surface sediments was carried out to monitor the dynamics of viruses, prokaryotes and MPB after inoculation with benthic or planktonic viruses. Benthic viruses modified the prokaryotic and MPB dynamics and decreased the photosynthesis efficiency in contrast to planktonic viruses that impacted MPB but not the prokaryotes.

Keywords: virus, prokaryotes, microphytobenthos, photosynthesis, sediment, mudflat

\section{INTRODUCTION}

Microbial communities are structured by the intrinsic activities of viruses (Sime-Ngando, 2014) in terms of diversity and dynamics, directly through the process of virus-mediated cell lysis and changes in metabolic properties and/or indirectly by the bioavailability of significant amounts of viral lysates that may infer a reduction in competition pressure (Suttle, 2007). The viral shunt of matter (Wilhelm and Suttle, 1999) tends thus (i) to promote the recycling of carbon and nutrients by bacterial remineralizers (Suttle, 2007), (ii) to reduce the transfer of organic carbon to higher trophic levels (Fuhrman, 1999) and (iii) overall to lubricate the microbial food-web on a shorttime scale (Weinbauer et al., 2009). In the water column, up to $25 \%$ of the bacterial community (Weinbauer, 2004) may be infected and viruses are assumed to account for $20-40 \%$ of the daily mortality of the standing stock of planktonic bacteria (Suttle, 2007) and for 10-30\% of the daily loss of bacterial production (Fuhrman, 1999). They affect both the biomass of phytoplankton (i.e., $10-50 \%$ of microalgae, Gastrich et al., 2004) and the photosynthesis, probably through metabolic 
reprogramming (Hurwitz et al., 2013), and reduce their primary productivity (Suttle et al., 1990; Juneau et al., 2003). Concerning the benthic deep-sea body, virus-induced mortality could globally represent as high as $80 \%$ of the benthic prokaryotic heterotrophic production (Danovaro et al., 2008a).

The so-called phage kills the winner concept (KtW; Thingstad and Lignell, 1997) was tested on a panel of planktonic and benthic data sets (Winter et al., 2010) and revealed a paradox in freshwater benthos where there is an apparent low infectivity of viruses together with an high abundance of bacterial hosts and viruses (Filippini et al., 2006). However, to question the universality of this paradox, the panel of environments considered needs to be enlarged, particularly in light of the fact that information on viriobenthos is scarce. Although, analyses have been performed on viriobenthos from a variety of sediments (rewiewed by Danovaro et al., 2008b; Middelboe et al., 2011; Helton et al., 2012) including surface layers in subtidal estuaries, coastal areas, continental lakes, and deep-ocean sediments, there is only parceled information of abundance concerning viriobenthos in the sediments of intertidal mudflats (Montanié et al., 2014; Careira et al., 2015).

In Western European macrotidal estuaries and semi-enclosed bays, the primary productivity of intertidal mudflats is supported by motile microalgae (microphytobenthos, MPB) which are generally dominated by diatoms and form the main component of a dense biofilm at the surface of the sediment at low tide (Pierre et al., 2012). The MPB biofilm is stabilized by the exudation of Exocellular Polymers Substances (EPS) by both microalgae and prokaryotes (Orvain et al., 2014a). These epipelic diatoms were shown to be highly resistant to light-temperature stress and its associated photooxidative stress, thanks to their motility and to the physiological non-photochemical quenching (NPQ) of chlorophyll $a$ fluorescence (Laviale et al., 2015).

The MPB biofilm is thus a unique transient biogeomorphological structure which constitutes a specific case study for in situ analyses of biological processes in surficial sediment. We investigated the dynamics and the activity of the viriobenthos associated with the MPB biofilm of the mudflat of Marennes-Oléron Bay (MOB; France) during the diurnal emersion period. The aims of our study were primarily, (1) to evaluate the temporal dynamics of viruses at the macro(monthly) and at the micro-scale (hourly) and their horizontal distribution, and (2) to estimate the viral production and the virus-induced prokaryotic mortality. Secondly, we postulated that part of benthic viruses may also originate from microalgae and may interact with their dynamics. We confronted the in situ data with ex situ experimental values obtained from sediment surface layers containing motile MPB and inoculated with benthic and planktonic viruses in order to question the viral impact on both heterotrophic prokaryotes and microalgae with a focus on the photosynthetic productivity of MPB.

\section{MATERIALS AND METHODS}

\section{Study Site and Sampling Stations}

Sampling was conducted at diurnal low tide, during the emersion period ( $4 \mathrm{~h}$ in length on average), on the mudflat located at the south end plume of the Charente estuary in Marennes-Oléron Bay $\left(45^{\circ} 53^{\prime} \mathrm{N} 01^{\circ} 07^{\prime} \mathrm{W}\right.$, France). Intertidal mudflats represent $60 \%$ of the bay at low tide (Figure S1). MPB can migrate vertically through the fine muddy sediment particles (median grain size around $11 \mu \mathrm{m}$ ) and may rapidly cover between 80 and $90 \%$ of the top-surface of the sediment during the first half of the emersion. First, a $4 \mathrm{~km}$ cross-shore transect was surveyed at three stations (1, 2, and 4, Figure S1) on 5 March 2003, 18 June 2003, 30 September 2003, and 1 February 2004. Secondly, five hourly surveys were performed during the diurnal emersion period at station 2 in 2008. Three cores were taken from each $4-\mathrm{m}^{2}$ quadra, randomly chosen in triplicate at each time-point within a $320 \mathrm{~m}^{2}$ study zone on the 19 and 20 February and $360 \mathrm{~m}^{2}$ on the 17,18 and 19 July, few days before the spring tide on the 22 February and 21 July (for details, see Orvain et al., 2014a). Samples were also harvested for ex situ experiments (15 May 2009 and 3 May 2010). In May 2009, the correspondence Weight/Volume was estimated as $1.29 \pm 0.02 \mathrm{~g}$ per $\mathrm{ml}$ of fresh sediment $(n=30)$, while the water content was $58.63 \% \pm 1.55$ (mean $\pm \mathrm{SD}, n=10$; range 52-65). Given this water content, $1 \mathrm{ml}$ of fresh sediment weighed $0.53 \mathrm{~g}$ after desiccation.

In each case, the $1 \mathrm{~cm}$ top surface sediment of three independent cores were sliced, pooled, and homogenized before sub-sampling in triplicate using $5 \mathrm{ml}$ sterile syringe corers; they were then fixed with $4 \%$-formaldehyde $(\mathrm{V} / \mathrm{V} ; 2 \%$ final concentration) and frozen $\left(-20^{\circ} \mathrm{C}\right) 1 \mathrm{~h}$ later until analysis within a week. In parallel, subsamples may serve to acquire environmental data: salinity, $\mathrm{Chl}$ a concentration measured using a Fluorometer Turner TD-700, water-content estimated by drying $\left(60^{\circ} \mathrm{C}\right.$ for $\left.12 \mathrm{~h}\right)$ and after a supplementary burning of $2 \mathrm{~h}$ at $490^{\circ} \mathrm{C}$ the concentration of organic matter (Table 1 ).

Water column samples were taken at the sub-surface at high tide on the same day, either on the vertical of station 2 (2003-2004 survey) or at station E (mouth of the Charente estuary; Auguet et al., 2005). Samples were fixed on board (36\%-formaldehyde, $1 \%$ final concentration), stored at $4^{\circ} \mathrm{C}$ and analyzed within $6 \mathrm{~h}$ in the laboratory.

\section{Extraction of Viruses}

Benthic viruses were extracted, in triplicate. Briefly, $1.0 \mathrm{ml}$ of tetrasodium pyrophosphate (10 mM final) and $3.6 \mathrm{ml}$ of Milli-Q water were added to a slurry of $400 \mu \mathrm{l}$ of fixed samples (i.e., $200 \mu \mathrm{l}$ of fresh sediment) defrosted at $37^{\circ} \mathrm{C}$, followed by $30 \mathrm{~min}$ of gentle shaking at $4^{\circ} \mathrm{C}$ on a rocking table and one centrifugation for $30 \mathrm{~min}$ at $1000 \mathrm{~g}$. Use of ultrasounds (Danovaro et al., 2001) have been discarded after a first test, confirmed then by a comparative test (July 2011) by which the accuracy of our method was analyzed on three sediment samples, in triplicate, by comparison with the extraction method using probe sonication instead of shaking (Sonimasse S20, two periods of $30 \mathrm{~s}$ at $60 \mathrm{~W}$ separated by 30 s of manual soaking).

This surfactant-procedure can occasionally be performed two or three times more with the pellet of the remaining settled sediment to test the efficiency of virus extraction, notably in February $(n=11)$ and July $2008(n=23)$, July $2011(n=9)$, and May $2013(n=12)$ and at each new sampling period in triplicate. The different supernatants, stemming from successive S-steps, were separately quantified immediately after recovery. 
TABLE 1 | Environmental data and Virus to Prokaryotes ratio within the $1 \mathrm{~cm}$-top surface sediment.

\begin{tabular}{|c|c|c|c|c|c|c|}
\hline & $\begin{array}{l}\text { Water-content } \\
\text { (WC) (\%) }\end{array}$ & $\begin{array}{c}\text { Decrease in WC } \\
\text { during emersion (\%) }\end{array}$ & $\begin{array}{c}\text { Change in pore-water } \\
\text { Salinity during } \\
\text { emersion (PSU) }\end{array}$ & $\begin{array}{l}\text { Organic matter Mass } \\
\qquad \mathbf{g ~ g}^{-1}(\%)^{\star}\end{array}$ & Chl $a \mu g^{-1 *}$ & $\begin{array}{c}\text { Virus to Prokaryotes } \\
\text { ratio (VPR) }\end{array}$ \\
\hline February 2008 & $61.7 \pm 0.7$ & 2.7 & $32-33$ & $0.079 \pm 0.001(8.6 \%)$ & $20.01 \pm 0.45$ & $0.85 \pm 0.49$ \\
\hline July 2008 & $51.3 \pm 0.4$ & $5.3-11.4$ & $37-42$ & $0.129 \pm 0.007$ (12.9\%) & $7.61 \pm 0.23$ & $9.61 \pm 3.31$ \\
\hline May 2009 & $52.6 \pm 0.5$ & nd & nd & nd & nd & $4.27 \pm 0.08$ \\
\hline May 2010 & $58.6 \pm 1.5$ & nd & nd & nd & nd & $1.89 \pm 0.34$ \\
\hline
\end{tabular}

Mean $\pm S D$. *per g of dry sediment.

Briefly, $2 \mathrm{ml}$ of a final dilution of 20, 200, and 400 times in MilliQwater (from the first to the third supernatant, respectively) were filtered through a $0.02 \mu \mathrm{m}$ Anodisc 25 membrane (Whatman) and stained with SYBR-green I (Noble and Fuhrman, 1998). Slides were immediately enumerated for virus counts (15 fields) under a blue light (filter set 38, Zeiss) at x1000 magnification on a Zeiss Axioskop 2 Mot Plus epifluorescence microscope (Carl Zeiss, Inc.) with a 100x Plan APO oil objective lens. For the comparative test of method of extraction, the supernatants have been also quantified by flow cytometry according to the protocol of Brussaard et al. (2010); $10^{-3}$ dilutions were stained by Sybrgreen $\mathrm{I}$ and $80^{\circ} \mathrm{C}$ heated for $10 \mathrm{~min}$ before the analysis using a FACSCanto II cytometer, calibrated with $0.47 \mu \mathrm{m}$ beads and the FACSDiva software.

\section{Virus Size and Morphology}

Viruses were first extracted in triplicate using pyrophosphate, a rocking shaker, and centrifugation as described above for the epifluorescence counts. Supernatants were pooled and ultracentrifuged for $3.5 \mathrm{~h}$ at $150,000 \mathrm{~g}$ (LE 70 Beckman ultracentrifuge, SW 28 rotor) and the pellet was resuspended in $100 \mu \mathrm{L}$ of TN buffer (0.02 M Tris-HCl, 0.4 M NaCl, pH 7.4). The diversity in shape and size was analyzed by TEM. Two carboncolodion coated grids ( $\mathrm{Cu} / \mathrm{Pd}$ grid, 300 mesh) were prepared per sample by negative staining using $2 \%$ phosphotungstate (Montanié et al., 2002). Observations were performed with a Jeol 2011 transmission electron microscope operating at $200 \mathrm{kV}$, calibrated with graphite grids, at a magnification of 50,000x to count at least 100 Virus Like Particles (VLP). Capsids were sized using Olympus analysis software.

\section{Prokaryotic Enumeration}

Triplicate samples $(5 \mathrm{ml})$, defrosted at $37^{\circ} \mathrm{C}$, were diluted 2000 times with $10 \mathrm{mM}$ tetrasodium pyrophosphate at serial dilutions of $0.5,10^{-1}$, and $10^{-2}$ [adapted from Pascal et al., 2009 and validated (Figure S2) by comparison with two other extraction methods using either cation-exchange resin (Lucas et al., 1996) or methanol Lunau et al., 2005]. A subsample was ultrasonicated for $30 \mathrm{~s}$ at $60 \mathrm{~W}$ (Sonimasse S20 sonicator), filtered onto a $0.2 \mu \mathrm{m}$ black polycarbonate membrane, and the prokaryotic cells stained with DAPI (Porter and Feig, 1980) then enumerated under UV illumination (filter set 01, Zeiss) at $1000 \mathrm{x}$ magnification on a Zeiss Axioskop 2 Mot Plus epifluorescence microscope (100x Plan APO oil objective lens). In the text, bacterial and archaeal cells are indifferently grouped as prokaryotes.

\section{Microphytobenthos (MPB) Counts}

Homogenized mud $(1 \mathrm{ml})$ was diluted 10 -fold with $<30-\mathrm{kDa}$ ultrafiltered seawater (obtained by tangential flow through polysulfone cartridge (Montanié et al., 2014). Then $0.5 \mathrm{ml}$ were diluted and fixed with $5 \mathrm{ml}$ of alkaline lugol (1\% final concentration). Algal cells were counted using a Nageotte chamber counter at $\mathrm{x} 40$ magnification on a Zeiss Axioskop microscope. MPB diatoms were divided into two groups: "small cells" which were mainly Navicula sp. and "large cells" which were mainly Pleurosigma and Gyrosigma spp., the so-called P-G taxon.

\section{In situ Viral Production and Virus-mediated Mortality of Prokaryotes}

In situ viral production was monitored during the emersion period as the net in situ viral abundance change by sampling, in triplicate (three independent cores), three randomly chosen quadras to evaluate the initial abundance and three other quadras to determine the change in viral abundance after $3 \mathrm{~h}$ of emersion. Samples were V/V fixed with $4 \%$ formaldehyde ( $2 \%$ final concentration) and frozen at $-20^{\circ} \mathrm{C}$. The lytic viral production (VP) was calculated as described by Luef et al. (2009) as the maximum minus the minimum viral abundance divided by the time elapsed. Virus-mediated mortality of prokaryotes (\% of cell loss per time unit; Weinbauer et al., 2010) was deduced by dividing VP by the burst size (BS) as the number of lysed cells (VLC) and then by reporting it to prokaryotic standing stock (PSS), assuming a constant BS of 36 (mean value in Corinaldesi et al., 2010). Virus-induced mortality of prokaryotes (VIM, \%) has also been evaluated as the ratio of lysed cells (VLC) to prokaryotic production (Danovaro et al., 2008a). The hourly carbon released by viral shunt from prokaryotes (VICR) was calculated assuming 79 fg C per cell (Saint-Béat et al., 2013) and weighted by the total Prokaryotic Carbon Demand (PCD) considering a bacterial growth efficiency of $31 \%$ in order to investigate the impact of viruses on C cycle (wVICR, Pinto et al., 2013).

\section{Ex situ Experiment: Viral Lysis}

To address and quantify the viral impact on benthic prokaryotes and microphytobenthos, only the free pore-water viruses were tested in order to avoid the time-consuming chemo-physical treatment during benthic extraction and to limit the input of mineral or organic matter detached from the biofilm. Pore-water viruses ("benthic viruses," Vb) were harvested by centrifugation 
at $3500 \mathrm{~g}$ for $10 \mathrm{~min}$ (Jouan CR412) of fresh sediment $(1 \mathrm{~cm}$ top-surface sediment), then filtered through a $0.2 \mu \mathrm{m}$ membrane to eliminate all other microbes. Additionally, viruses in the water column ("planktonic viruses," Vp) were isolated from other organisms by filtration of the overlying seawater through a $0.2 \mu \mathrm{m}$ filter. In May 2010, heat-inactivated Vb (boiled and cooled 3 times) were tested.

Sub-samples of fresh sediment $(6 \times 2 \mathrm{ml})$ were incubated in 6-well microplates (Falcon), humidified top-down either with $250 \mu \mathrm{l}$ of virus-free pore-water ("Control") or $250 \mu \mathrm{l}$ of benthic or planktonic viruses ("Vb or Vp treatment"). Virus-free porewater was obtained by ultrafiltration of the virus-rich filtrate using a centrifugation filter device (Centricon Plus-70 Ultracel PL-30, Millipore). The 6-well-microplates were exposed to natural light at ambient temperature in order to maintain the in situ migratory behavior of MPB cells. Time-series sampling was performed daily in triplicate at the corresponding time of mid low tide in the field (using a $1 \mathrm{ml}$ syringe corer after homogenization of the well, with a coefficient of variation of $13.41 \%)$. The impact of pore-water viruses on the prokaryotes was estimated over three consecutive days in May 2009 and 2010. Daily viral production and virus-mediated mortality of prokaryotes were calculated for the concomitant period of prokaryotic decrease and viral increase (Luef et al., 2009). Total prokaryotic loss was estimated as the net decrease in abundance (i.e., net prokaryotic production; Middelboe et al., 2006).

In May 2009, viral lysis activity of $\mathrm{Vb}$ was also evaluated on MPB over seven days and compared to Vp lysis activity. To counteract the possible evaporation of water from the sediment, $250 \mu \mathrm{l}$ of virus-free pore water was added to each well at day 3 .

\section{Photosynthetic Activity of the MPB ex situ: Maxi-imaging-pam Chlorophyll Fluorescence Measurements}

Chlorophyll fluorescence measurements were performed with the Maxi-version of an Imaging-PAM chlorophyll fluorometer (I-PAM, Walz, Effeltrich, Germany) on a 6-well microplate, which occupies the total surface of the fluorescence image $(10 \times 13 \mathrm{~cm}$; Figure S3). Three wells (one horizontal row) used for one kind of treatment only (control, $\mathrm{Vb}$ - or $\mathrm{Vp}$-) enabled instantaneous triplicate measurements (Figure S3). The photosynthetic activity of the MPB was assessed by rapid light curve (RLC) measurements (Perkins et al., 2010). RLCs were obtained by the application of a series of 11 sequential short light exposures $(20 \mathrm{~s})$ with increasing irradiance from 0 to $1250 \mu \mathrm{mol}$ photons. $\mathrm{m}^{-2} \mathrm{~s}^{-1}$. At each irradiance, $F_{m}^{\prime}$ and $F_{t}$ were recorded. $F_{m}^{\prime}$, the maximum fluorescence yield, was measured by applying a saturation pulse $(800 \mathrm{~ms}, 2800 \mu \mathrm{mol}$ photons. $\left.\mathrm{m}^{-2} \mathrm{~s}^{-1}\right) ; F_{t}$, the steady-state fluorescence, was continuously monitored throughout each $20 \mathrm{~s}$ light step. $F_{0}^{\prime}$, the minimum fluorescence yield, was measured at irradiance $0 \mu \mathrm{mol}$ photons. $\mathrm{m}^{-2} \mathrm{~s}^{-1}$ by measuring non-actinic light solely.

Two main parameters were computed from the RLCs: (i) $\Phi P S I I$, the effective quantum yield of photosystem II (PSII), was calculated for the $0 \mu \mathrm{mol}$ photons $\mathrm{m}^{-2} \mathrm{~s}^{-1}$ irradiance as $\Phi$ PSII $=$ $\left(F_{m}^{\prime}-F_{t}\right) / F_{m}^{\prime}$. As no adaptation to the dark was performed before the measurement in order to avoid vertical migration of the motile microalgae, $F_{t}$ (or $F_{0}^{\prime}$ ) and $F_{m}^{\prime}$ were close to their respective dark-adapted values $F_{0}$ and $F_{m}$, so that $\Phi$ PSII at this irradiance is close to the standard fluorescence index $F_{v} / F_{m}$, i.e., the maximum photosynthetic efficiency of PSII (Ralph et al., 2010), and (ii) NPQ, the non-photochemical quenching of chlorophyll fluorescence, was calculated as NPQ $=F_{m}-F_{m}^{\prime} / F_{m}^{\prime}$ (Ralph et al., 2010). The NPQ kinetics were further measured during a short (5 min) light exposure of $280 \mu \mathrm{mol}$ photons $\mathrm{m}^{-2} \mathrm{~s}^{-1}$, which was close to the intensity necessary to saturate photosynthesis (249 $\pm 50 \mu \mathrm{mol}$ photons $\mathrm{m}^{-2} \mathrm{~s}^{-1}$ ) for the control MPB biofilm, as measured using the RLCs.

\section{Statistical Analysis}

All statistics were performed with Excel and Prism 4 softwares or Minitab for nested ANOVA. Regression analysis was performed for prokaryote abundance and prokaryote loss against viral abundance and VPR, respectively, using log-transformed data.

\section{RESULTS}

\section{Efficient Protocol for Viral and Bacterial Extraction and Counting from Sediment}

To extract viruses, sonication has been rejected because it emulsified the mud-samples and the sediment was disrupted into smaller particles that decreased the accuracy of the microscopic observation of viruses. Therefore, in the test of July 2011 (Figure 1), the microscopic abundance significantly lowered (ANOVA, $p=0.0002$ ) as well as cytometric counts (ANOVA, $p<0.0001$ ). The method of extraction (with or without sonication, nested ANOVA) accounted for $73.8 \%$ of total variance by microscopy and for $78.9 \%$ by cytometry. The accuracy of the protocol used for viruses (July 2011 test, $n=3$ ) was illustrated by a coefficient of variation (CV) of $16.4 \pm 8.4 \%$ instead of $19.3 \pm$ $5.6 \%$ with the sonication step, and this difference in CV was confirmed by flow cytometry analysis $(2.6 \pm 1.9 \%$ vs. $13.3 \pm$ $4.5 \%)$.

The addition of EDTA (Helton et al., 2006; Careira et al., 2015) was not conclusive for the same reason while vortexing has made the grids opaque for observation. After having tested our protocol on several extraction-steps, its efficiency seemed satisfactory. The first two steps (S1 and S2) involving pyrophosphateshaking detected up to $99.6 \%$ of extractable viruses; a third step removed only $0.4 \%$ of the total cumulative number. The first and second steps extracted $63.9 \pm 6.9$ and $36 \pm 1 \%(n=34$, in situ data of 2008) of the extractable viruses, respectively. Overall to date, all acquired data posteriorly validated that the first S1-extraction corresponded to $64.1 \pm 8.1 \%$ of extractable viruses ( $n=56$, Figure 2). For samples of 2009-2010 after a preliminary confirmation of the percentage of extractability, only one step was performed for in vitro counts and the initial extractable virus numbers was then corrected for the miscounting based on the determined $64 / 36 \%$ ratio of S1/S2 extraction efficiency.

All samples were stored at $-20^{\circ} \mathrm{C}$ for a week and no factor was ever applied for correcting the viral loss due to fixation with 

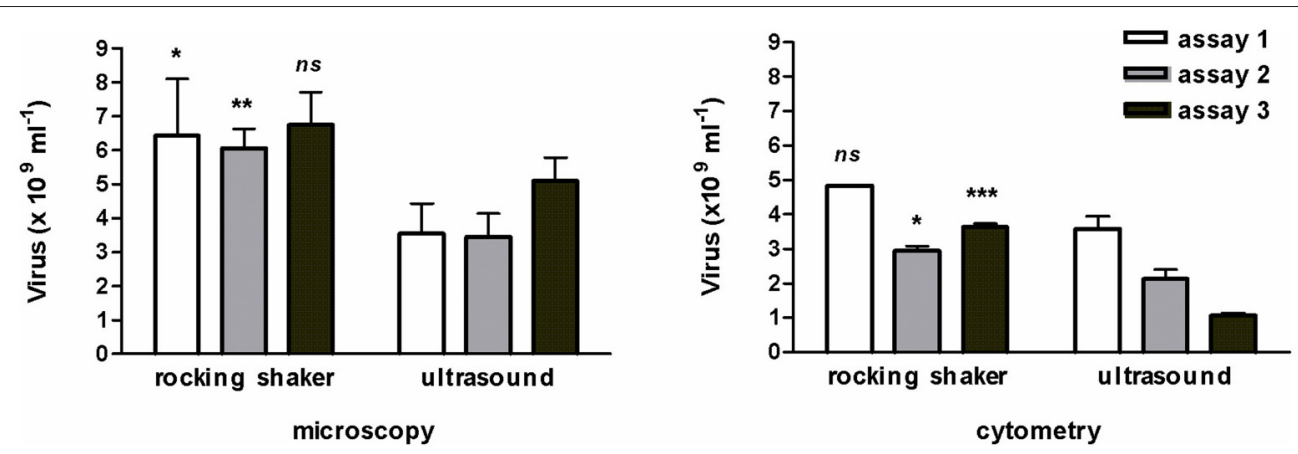

FIGURE 1 | Comparative test for viral extraction from muddy-sediment by shaking or sonication. Reports of three assays performed in triplicate and analyzed by microscopy and cytometry $\left(n=3\right.$, mean \pm SE). ns, non-significant, ${ }^{*} p<0.05 ;{ }^{* *} p<0.01 ;{ }^{* *} p<0.001$.

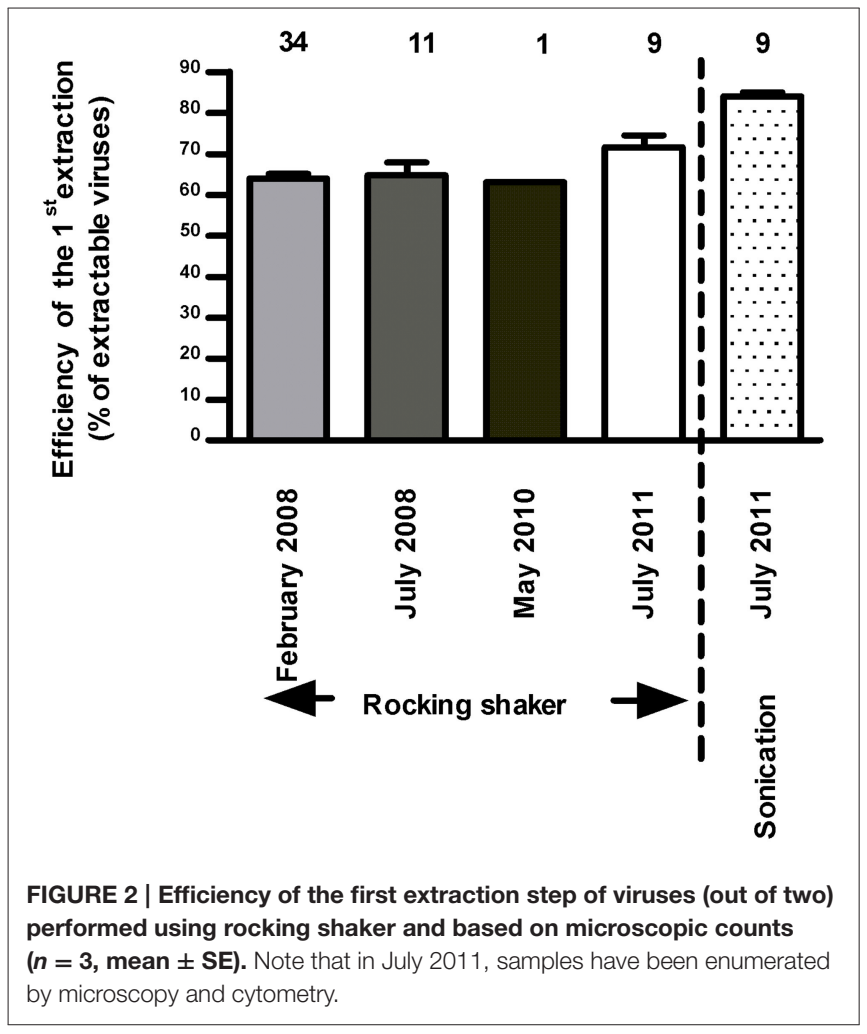

formaldehyde and conservation. Indeed a time-point comparison of the decay of viruses included into muddy samples and stored for 15 days at $4^{\circ} \mathrm{C},-20^{\circ} \mathrm{C}$, and $-80^{\circ} \mathrm{C}$ (Figure 3), revealed (i) no significant variation in virus counts after 8 days of storage at each or other temperature $(p>0.05)$, even if curiously the number of extracted viruses from samples stored at $4^{\circ} \mathrm{C}$ was higher after 1 day, (ii) irrespective of temperature, a significant loss of viruses between $8 \mathrm{~d}$ and $15 \mathrm{~d}$ of storage $(p<0.0001)$ and thus significant lowered $T_{15}$ values compared to initial field value $(p<0.001)$ and (iii) at each time point, a higher preservation in refrigerated samples $\left(4^{\circ} \mathrm{C}\right)$ than in frozen samples $\left(-20^{\circ} \mathrm{C}\right.$ and $\left.-80^{\circ} \mathrm{C}, p<0.001\right)$ without any difference between the two freezing temperatures $(p>0.05)$. However, the percentage of
S1 recovery declined over time in line with increased negative temperature of preservation (Figures 3B-D).

A significant fraction of the prokaryotes was not eluted with the extraction procedure used for viruses, despite three sequentially repeated extractions. Prokaryotes were thus counted independently from viruses with a protocol previously used in our laboratory for benthic prokaryotes (Pascal et al., 2009). Our protocol consists in ultrasound treatment of highly diluted sediments followed by a DAPI staining (Figure S2). The counting procedure was not disturbed by the accumulation of sediment particles inappropriately masking the microscopic slides.

\section{Monthly Survey of Viral and Prokaryotic Abundance}

On a monthly average, the abundance of viriobenthos was 60fold higher than that of virioplankton $(60.3 \pm 20.3, n=7)$. The abundance of benthic prokaryotes varied between $244 \pm 13$ (May 2009-July 2008) and 1945 times higher (February 2008) than those in the water column.

In 2003-2004, at all stations along the transect, viral abundance peaked to $2.43 \pm 0.46 \times 10^{9}$ viruses $\mathrm{ml}^{-1}$ in September then dropped to $c$. $0.9-1 \times 10^{9} \mathrm{ml}^{-1}$ in winter (Figure 4A). The sampling date accounted for $77.2 \%$ of the total variance in viral abundance while spatial location accounted only for $5.7 \%$.

A large morphological diversity in virus-like particles (VLPs) was observed using transmission electron microscopy (Figure S4). The majority of VLP showed icosahedral shape, only few pleomorphic particles or elongated capsids were observed. Some filamentous forms of $0.6-1.2 \mu \mathrm{m}$ were observed, notably in February and September (3-8\%). Excluding filamentous VLPs, the capsid size was on average $77.4 \pm 34.9 \mathrm{~nm}$. Tailed viruses accounted for $4-21 \%$ of the particles and theirs capsids were on average $96.4 \pm 25.7 \mathrm{~nm}$ in size. Because of the low frequency of tailed VLPs, their morphotypes were not discriminated between myovirus, siphovirus, or podovirus shape; however the largest particles could be address to Myoviridae. The distribution of capsid diameters provided accurate seasonal morphological comparisons (Figure 4B). Throughout the year, VLPs less than $65 \mathrm{~nm}$ in size constituted up to $36-49 \%$ of the 


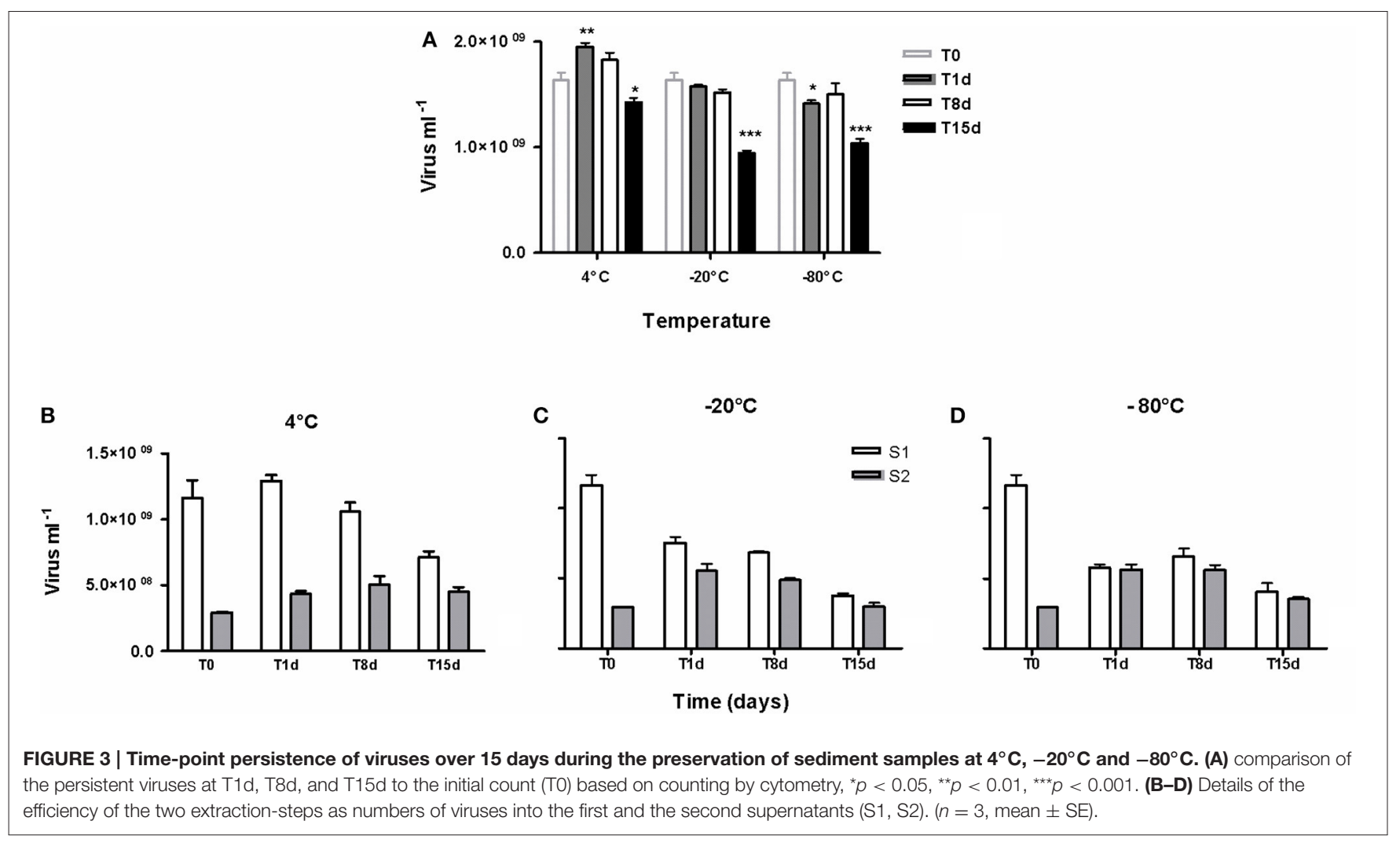

total particles, depending on the frequency of the $<45 \mathrm{~nm}$ sized particles $(17-19 \%$ in winter vs. $5-9 \%$ in summer and autumn). The largest size-class (>125 $\mathrm{nm}$ ) represented $4-21 \%$ of the total VLPs varying from 0.36 (March) to $3.85 \times 10^{8}$ (June). In September, the 65-85 nm-sized particles was 5-fold higher than in the others months and predominated the viral community (42\%). Tailed viruses accounted for $9-33 \%$ of their size-class. It was noticeable that, in February 2004, 22\% of the VLPs were longer than $105 \mathrm{~nm}$, and $38 \%$ of these were tailed viruses.

\section{In situ Hourly Survey of Viral and Prokaryotic Abundance During an Emersion Period in Winter and Summer}

In the top-surface sediment of the mudflat, viral abundance at the beginning of the emersion was c. $1.91 \pm 0.22 \times 10^{9} \mathrm{ml}^{-1}$ in February 2008 and c. $6.30 \pm 0.47 \times 10^{9} \mathrm{ml}^{-1}$ in July 2008 (Figure 5A). Prokaryotes numbers were $3.19 \pm 0.45 \times 10^{9}$ cells $\mathrm{ml}^{-1}$ and $8.48 \pm 1.37 \times 10^{8}$ cells ml ${ }^{-1}$, respectively (Figure 5B). Consequently, the Virus to Prokaryotes Ratio (VPR) was on average $0.85 \pm 0.49(n=6)$ in February and $9.61 \pm 3.31(n=8)$ in July (Table 1).

Viral abundance increased during the $3 \mathrm{~h}$ of diurnal emersion on the 19th and 20th February 2008 ( $+47 \%$ and 9\%, respectively; Figure 5A) with no clear tendency for prokaryotes, resulting in an insignificant relationship between viruses and prokaryotes $(p>0.05)$. On average, the hourly viral production (VP) was
$2.23 \times 10^{8}$ viruses $\mathrm{ml}^{-1} \mathrm{~h}^{-1}$, and was responsible for $0.22 \pm$ $0.04 \%$ of prokaryotic loss (in terms of prokaryotic standing stock, PSS). In summer, significant viral replication occurred on the 17,18 , and 19 July 2008 ( $t$-test, $p=0.0037 ;+22.41 \pm 4.74 \%$ ) while prokaryotes concomitantly decreased $(-5.44 \pm 1.97 \%$ $\mathrm{h}^{-1}$; Figure 5B). Viruses accounted for $84 \%$ of the variation in prokaryotic abundance (log Prokaryotes $=-1.63 \log$ Viruses $\left.+24.90, r^{2}=0.84, n=6, p=0.01\right)$. In July 2008, VP was $4.39 \pm 1.4210^{8}$ viruses $\mathrm{ml}^{-1} \mathrm{~h}^{-1}$, representing a loss of $1.52 \pm 0.56 \%$ of PSS. Virus-mediated prokaryotic lysis accounted for $28.99 \pm 5.61 \%$ of observed prokaryotic cell loss (i.e., the net prokaryotic growth). Moreover, considering that the gross prokaryotic production was 3.21 and $3.84 \%$ of the standing stock per hour (Production/Biomass; P/B), in winter and summer 2006 respectively (Pascal et al., 2009), virus-induced mortality (VIM) could account for $6.78 \pm 1.44 \%$ of the prokaryotic production in February 2008 and for $39.7 \pm 14.7 \%$ of prokaryotic production in July 2008. However, whatever the season, the viral turnover averaged $0.099 \pm 0.082 \mathrm{~h}^{-1}$ (range 0.059-0.236), slightly higher in winter (0.14) than in summer (0.07). During the diurnal emersion, between 3.12 and $15.83 \mathrm{mg} \mathrm{C} \mathrm{m}^{2}$ would be released by viral shunt per hour (i.e., VICR) and the released $\mathrm{C}$ may represent around $2.1 \%$ (winter) and $12.3 \%$ (summer) of the Prokaryotic Carbon Demand (i.e., weighted VICR).

Interestingly, by using all the in situ data (February 2008, July 2008, May 2009, and May 2010), a significant negative relationship was observed between the virus to prokaryotic ratio (VPR) and the water content of the sediment $(p<0.0001$; 
Figure 6A). A higher prokaryotic abundance was observed when the water content exceeded 58.6\%, expressed in fine as a lower VPR (<2, February 2008 and May 2010 vs. $4.3<$ in July 2008 and May 2009; Table 1). And during the emersion period and whatever the season, the viral production (VP) tended to be negatively linked to water content and the magnitude of change in VPR was positively and significantly related to viral production $(r=+0.88 ; p=0.01)$. When the net positive prokaryotic growth
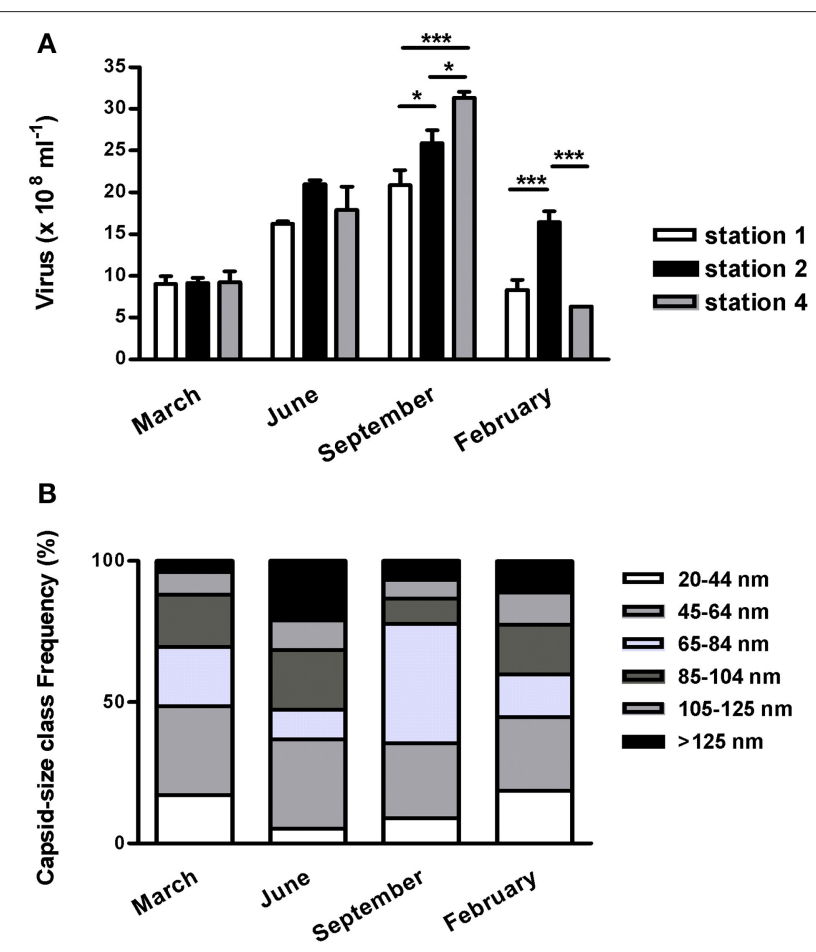

FIGURE 4 | Seasonal survey of viriobenthos at the diurnal emersion period of the Marennes-Oléron mudflat in 2003-2004. (A) abundance along a $4 \mathrm{~km}$ cross-shore transect (stations 1-4; see Figure S1); mean $\pm \mathrm{SE}$. (B) Virus distribution by capsid class sizes; mean of the three stations surveyed. Only significant spatial heterogeneity between the three stations (Two ways ANOVA) were marked as ${ }^{*} p<0.05,{ }^{* * *} p<0.001$. represented more than $19.5 \%$ of the PSS, VPR tended to decline during emersion (Figure 6B).

\section{Daily Monitoring of Top-surface Spring Sediments Maintained ex situ: Viral Inoculation and Virus-mediated Prokaryotic Lysis}

In May 2009, in the top-surface mud layer, there were c. $2.81 \pm$ $0.32 \times 10^{9} \mathrm{ml}^{-1}$ viruses and c. $6.58 \pm 0.08 \times 10^{8} \mathrm{ml}^{-1}$ prokaryotes, corresponding to $c .5 .30 \pm 0.61 \times 10^{9}$ and $c .1 .29 \pm 0.01 \times 10^{9}$ $\mathrm{g}^{-1}$ dry sediment, respectively. The VPR was on average $4.27 \pm$ 0.08. In May 2010, viral abundance was only $1.89 \pm 0.34$ times the prokaryotic abundance (c. $4.31 \pm 0.19 \times 10^{9}$ vs. c. $2.22 \pm$ $0.07 \times 10^{9} \mathrm{ml}^{-1}$ or c. $8.13 \pm 0.35 \times 10^{9}$ vs. c. $4.18 \pm 0.14 \times 10^{9}$ $\mathrm{g}^{-1}$ dry sediment).

In response to the addition of pore-water viruses $(\mathrm{Vb})$ ( $+7.87 \%$ in 2009 and $+3.84 \%$ in 2010 ), a daily increase in PSS loss was observed: $+7.11 \%$ in 2009 and $+11.69 \%$ in 2010 . In 2009 (Figure 7E), viral abundance decreased during the first day, notably in control wells. A net viral production occurred during the second day while prokaryotic abundance was still decreasing. By day 3, viral and prokaryotic dynamics diverged between the control wells and virus-treated wells. In both cases, viruses rose back to their initial titers, while prokaryotes nearly doubled in controls compared to samples treated with viruses (Figures 7D,E). During the 3 days of incubation, the amplitude of variation in viral abundance was more pronounced in the controls than in virus-treated wells and thus was characterized by a higher VP: $4.73 \times 10^{8}$ vs. $3.93 \times 10^{8}$ viruses $\mathrm{ml}^{-1} \mathrm{~d}^{-1}$. However, during the first 2 days, viral abundance was significantly higher in virus-treated wells, leading to an increase of $1.07 \%$ in virusmediated loss of PSS. Otherwise, no significant relationship was observed between viral and prokaryotic abundance $(r=0.32$; $p=0.45$ ).

In contrast, in May 2010 (Figure 8), prokaryotic abundance decreased significantly with increasing viral abundance (log Prokaryotes $=-1.46 \log$ Virus $+23.43, r^{2}=0.89, n=8$, $p<0.001)$ whatever the treatment. One day post inoculation, prokaryotic abundance was significantly reduced with the $\mathrm{Vb}$ treatment compared to controls ( $t$-test, $p<0.05$ ) while
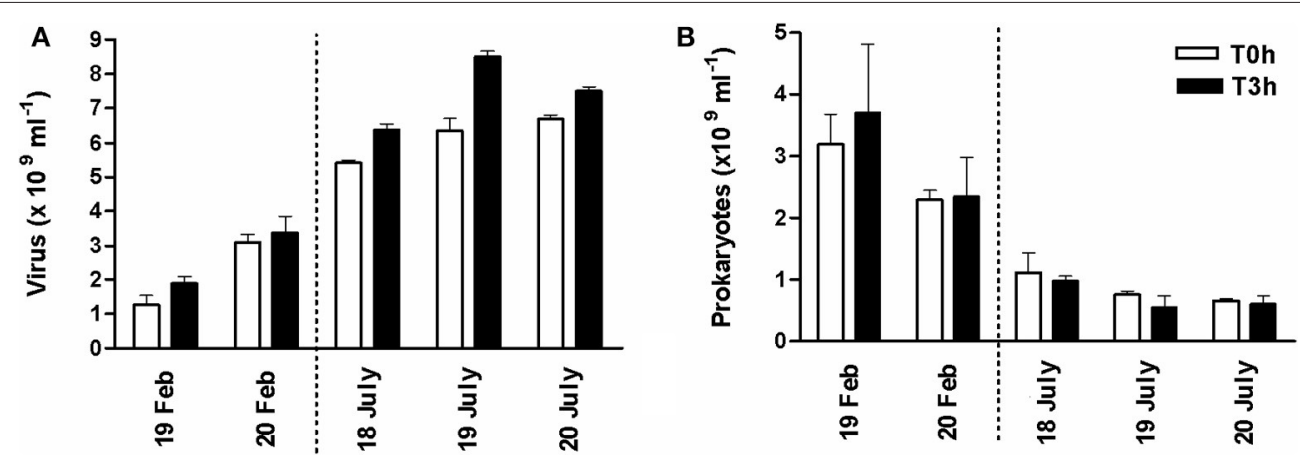

FIGURE 5 | Hourly survey of (A) viriobenthos and (B) prokaryotes during the diurnal emersion period in February and July 2008 . Abundance at the beginning of the emersion and $3 \mathrm{~h}$ later at station 2 of the transect (see Figure S1); mean of triplicate samples from three randomly chosen quadras \pm SE. 


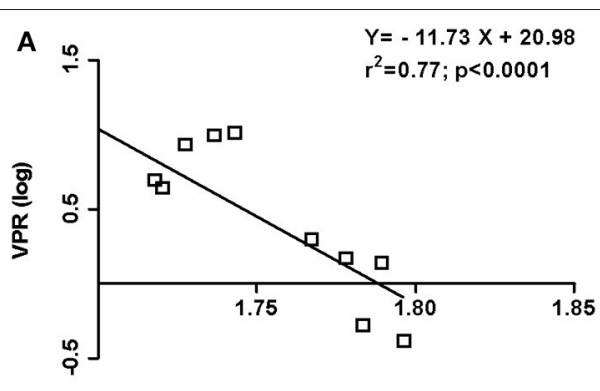

Water Content (log)

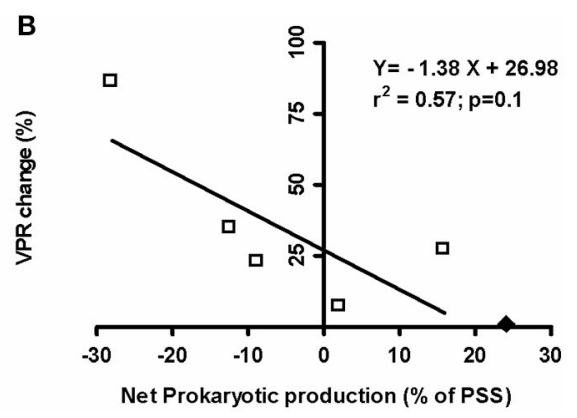

FIGURE 6 | In situ Virus to Prokaryote ratio (VPR) in the top-surface sediment.(A) Log/log relationship between VPR and the water content of the sediment, established with data averaged from triplicate samples taken in February and July 2008, May 2009 and May 2010 (B) Relationship between the variation of VPR during the $3 \mathrm{~h}$ of emersion and the net prokaryotic production (\% of prokaryote stock standing) in February and July 2008. With : outer data of 21 July 2008 , the relationship would be: $Y=-1.38 X+28.32\left(r^{2}=0.66 ; p=0.05\right)$.

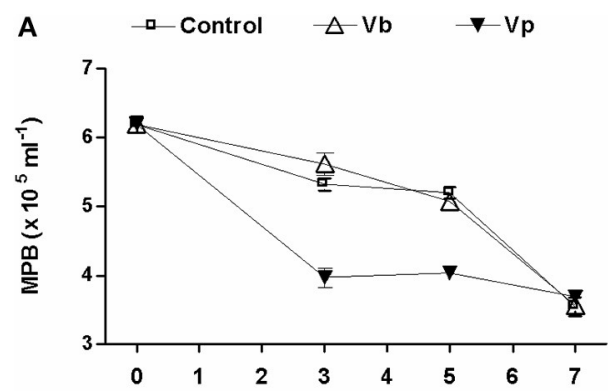

B
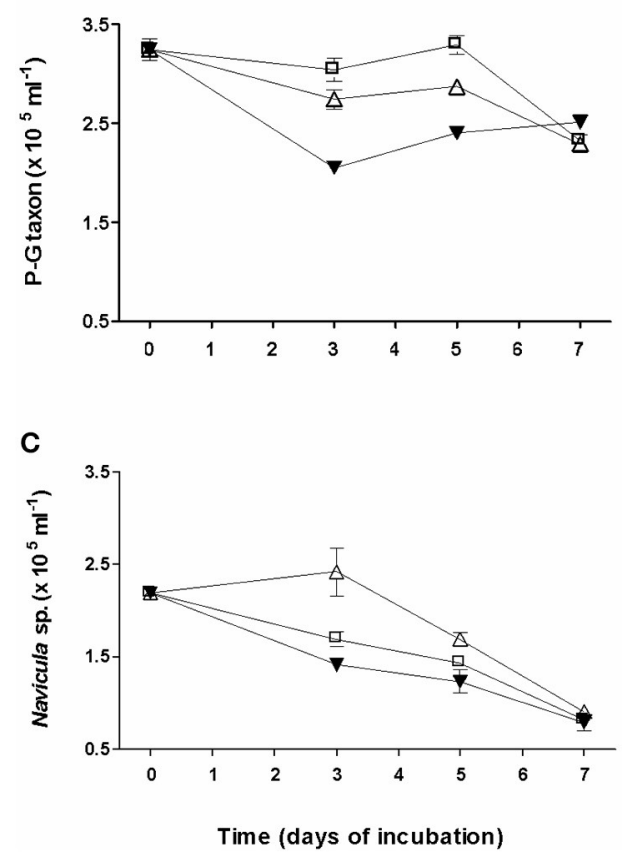

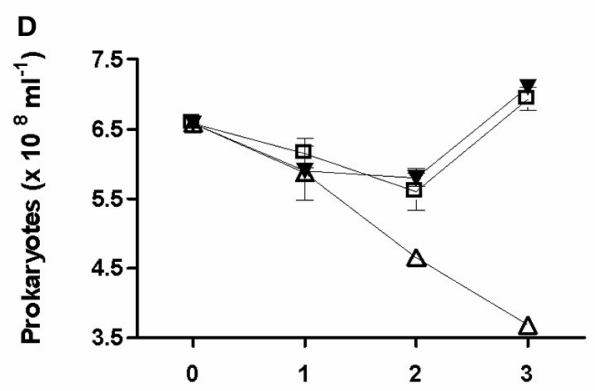

E

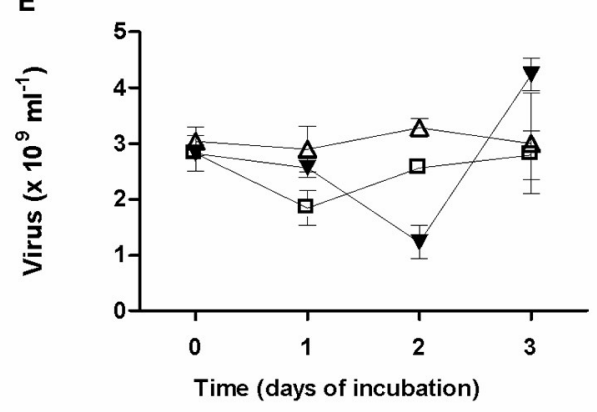

FIGURE 7 | Viral inoculation of top-surface sediment in microplates, in May 2009. Virioplankton (Vp) and viriobenthos (Vb) were added and the two treatments were compared to the non-amended control. Time series over 3 days of the abundance of (E) viruses, (D) prokaryotes, and over 7 days of the abundance of (A) microphytobenthos with a focus on their dominant taxa, Pleurosigma-Gyrosigma taxon (P-G taxon; B), and Navicula sp. taxon (C). Mean \pm SE of three well-samplings. 


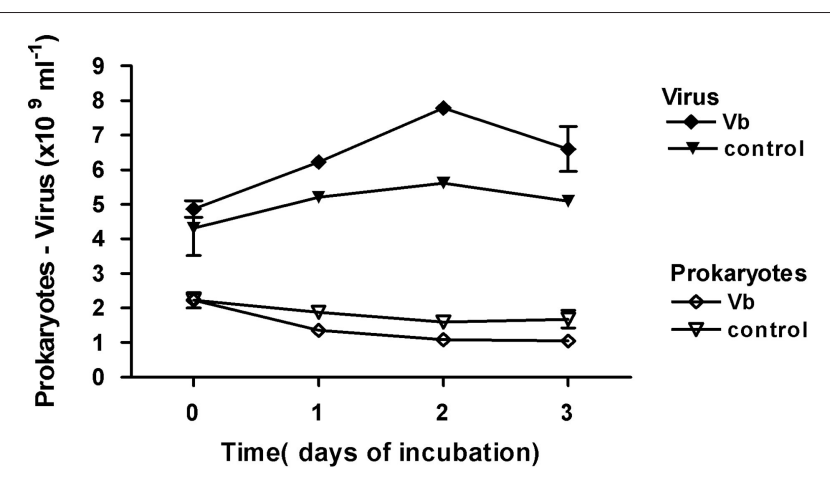

FIGURE 8 | Viriobenthos inoculation of top-surface sediment in microplates, in May 2010. Viriobenthos $(\mathrm{Vb})$ treatment was tested in comparison with the non-amended control. Time series over 3 days of the abundance of viruses and prokaryotes; mean \pm SE of three well-samplings.

TABLE 2 | Photosynthetic parameters of controls (untreated) and virus-treated microphytobenthic biofilm after a five day infection.

\begin{tabular}{lccc}
\hline & Control & Virus-treated Vb & Virus-treated Vp \\
\hline$F_{V} / F_{m}$ & $0.71 \pm 0.01$ & $0.65 \pm 0.01$ & $0.63 \pm 0.01$ \\
$N P Q$ & $1.35 \pm 0.01$ & $1.15 \pm 0.04$ & $1.30 \pm 0.03$ \\
\hline
\end{tabular}

$F_{v} / F_{m}=$ the maximum photosynthetic efficiency of $P S I I . N P Q=$ the non-photochemical fluorescence quenching measured at a light intensity of $280 \mu \mathrm{mol} \cdot$ photons $\cdot \mathrm{m}^{-2} \cdot \mathrm{s}^{-1}$ which is known to saturate the photosynthetic electron transport rate (rETR) for the control biofilm (the light intensity required to attain rETR $\max , E_{m}=249 \pm 50 \mu \mathrm{mol} \cdot$ photons $\cdot \mathrm{m}^{-2} \cdot \mathrm{s}^{-1}$ ). Values are means $\pm S D$ of three measurements.

inactivated $\mathrm{Vb}$ had no effect ( $t$-test, $p=0.5$ ). The daily viral production, calculated over the first 2 days in control wells, was $6.48 \times 10^{8} \mathrm{ml}^{-1} \mathrm{~d}^{-1}$ of fresh sediment. In virus-treated wells, an additional viral production occurred, c. $8.09 \times 10^{8} \mathrm{ml}^{-1} \mathrm{~d}^{-1}$, which was responsible for the supplementary lysis of $1.01 \%$ of PSS. By combining the data from May 2009 and May 2010 with the in situ data from July 2008, a significant positive relationship between loss of prokaryotic abundance and VP was estimated as: prokaryotic loss $=-0.759 \times \mathrm{VP}-1.088\left(r^{2}=0.79, n=5\right.$, $p=0.04)$.

In May 2009, the influence of $\mathrm{Vp}$ was also tested (Figures 7D,E). Only 6\% of PSS was lost per day compared to $7.5 \%$ in the controls and $14.6 \%$ with $\mathrm{Vb}$. However, daily VP reached $3 \times 10^{9}$ particles $\mathrm{ml}^{-1}$.

\section{Daily Monitoring of Top-surface Spring Sediments Maintained in vitro: MPB Dynamics and Photosynthesis as a Function of Viral Inoculation}

The analysis of the microphytobenthos (MPB) was only conducted in May 2009 (Figure 7). MPB biomass evolved similarly in the control and virus $\mathrm{Vb}$-treated wells (Two way ANOVA, $p=0.363$; Figure 7A). Of the $6.15 \pm 0.11 \times 10^{5}$ cells $\mathrm{ml}^{-1}$ in the top-surface sediment, pennate diatoms largely dominated over centric species (stable at around 12-13\%, whatever the treatment), of which $59.6 \%$ belonged to the
Pleurosigma-Gyrosigma taxon (P-G taxon) and $40.4 \%$ to Navicula sp. In controls, a slight decline (3.1\% per day) was noticeable until day 5 , followed by a sharp decrease since only $57 \%$ of the original assemblage persisted at day 7 (Figure 7A). Within the first 3 days, the P-G taxon (Figure 7B) decreased slightly more $(-9.8 \%)$ in the Vb-treated wells than in the control wells while the growth of Navicula sp. (Figure 7C) was significantly enhanced $(+42.9 \%$, ANOVA, $p=0.045)$. From days 3 to 5 , the P-G taxon biomass regained its level at $T=0$ in control and, although a net increase was observed whatever the treatment, its biomass was significantly higher in the control wells than in the Vb-treated wells ( $+12.9 \%$; ANOVA, $p=0.017)$. The abundance of Navicula sp. decreased by $30 \%$, but the number of cells was still significantly higher in $\mathrm{Vb}$-treated wells than in the controls wells $(+18.7 \%$, ANOVA, $p=0.04)$. At ay 7 , no difference in abundance was observed whatever the treatment (ANOVA, $p=0.81$ and 0.16 for the P-G taxon and Navicula sp., respectively). At that time, the loss in MPB biomass from T0 on was largely due to Navicula sp. (63\%) while only $28 \%$ was due to the P-G taxon.

The addition of Vp significantly changed the MPB dynamics (Two way ANOVA, $p<0.001$ ) by doubling the MPB decay rate to $6.9 \% \mathrm{~d}^{-1}$ vs. 3.1 and $3.6 \%$ for controls and Vb-treatment, respectively (Figure 7A). P-G taxon (Figure 7B) was significantly less represented than in the control wells over the 5 days $(p<$ 0.008). In contrast, the number of Navicula sp. cells (Figure 7C) was only significantly lower at day 3 (ANOVA, $p=0.04$ ).

After 5 days of viral infection, the photosynthetic activity of the MPB biofilm was measured with a Maxi-Imaging-PAM fluorometer. The basic chlorophyll fluorescence emission of MPB $\left(F_{t}\right)$, which illustrates the photosynthetic biomass, was similar in the control and virus-treated wells (Figure S3). This confirmed the results of MPB-cell counting. Nevertheless, the maximum photosynthetic efficiency $\left(F_{v} / F_{m}\right)$ was clearly reduced in all virus treated-wells ( $\mathrm{Vb}$ and $\mathrm{Vp}$ ) compared to the control sediment (Table 2). It was noticeable that NPQ, the non-photochemical quenching of fluorescence, which is an index of light stress photoprotection, decreased in Vb-treated sediment but not in Vp-treated sediment, compared to the control (Table 2). Measurement of the NPQ development kinetics showed that not only the extent of NPQ was reduced but that the kinetic was slowed down by $\mathrm{Vb}$ infection (Figure S5). After 10 days of viral infection, the photosynthetic efficiency strongly decreased in all samples, illustrating the senescence of the MPB biofilm; there was no longer any difference between controls and virus-treated sediments (data not shown).

\section{DISCUSSION}

\section{Methodological Considerations}

Comparative storage of sediment samples allows to conclude to a relatively good persistence of viruses at short-term (a week) at $4^{\circ} \mathrm{C}$ as well as freezing temperatures. While the loss of viruses may be up to $35 \%$ in $24 \mathrm{~h}$ (according to the exponential model of decay, Wen et al., 2004), a gain of viruses (+19\%) was detected in $24 \mathrm{~h}$ at $4^{\circ} \mathrm{C}$ like in the case of lacustrine sediment 
(up to $31 \%$ in 5 days, Duhamel and Jacquet, 2006). Changes in the structure of the sediment matrix (organic matter and siltclayed substratum) may modify the extractability of the viruses and their sorption capacity to the plastic tube-wall according to the extended-DLVO theory (Helton et al., 2006; Gutierrez and Nguyen, 2012; Wong et al., 2013). The apparent higher viral counts at $24 \mathrm{~h}$ may be consecutive to a stark release in pore water of colloidal EPS from microalgae and bacterial cells. EPS may help to desorb viruses by reducing the minimum energy depth and increasing steric hindrance (Walshe et al., 2010; Zhao et al., 2014) and then favor their persistence by inhibiting the extracellular nuclease or protease (Hewson et al., 2012). They may finally limit the bias of sorption on the plastic tube-wall of tube by complexing viruses in solution (Wong et al., 2013). Forehand, the recurrent loss of viruses into frozen samples compared to refrigerated samples may result from the disruption of cells due to ice crystal disruption (Helton et al., 2006) and the subsequent release of virucidal substances. Inversely no differences were reported for sediments of the Chesapeake Bay that contains greater proportion of sand and smaller percentage of organic matter (Helton et al., 2006).

Roughly, $64 \%$ of the extractable viruses were dislodged during the initial extraction step. This is similar to values reported for estuarine sediments from other sites (Helton et al., 2006; Danovaro and Middelboe, 2010). Given the physical properties of the sediment, an ultrasound treatment was recommended by Danovaro and Middelboe (2010) and Careira et al. (2015). Nevertheless, in our case, the presence of very small silt-clayed particles (up to 98\%; Blanchard et al., 1997) precluded the use of a physical treatment (ultrasound and vortex). Indeed, compared to sandy sediment, the higher total porosity and lower permeability of muddy sediment favors the enhancement of the electrostatic forces between clayed particles and virions (Gerba, 1984; Helton et al., 2006) and a slow desorption of viruses (Pinto et al., 2013). Although, the adaptation of the extraction protocol we propose here for highly clayed sediments can be considered as conservative for viral extraction, it could not be validated for the extraction of prokaryotes.

Given the intertidal nature of the Marennes-Oléron bay (MOB), we made improvements to the methodology for the determination of viral production (VP). Estimates of viral increase over time is standard for marine sediments either by incubating (1) undiluted and homogenized deep-sea sediments in a Würgler-bag in anoxic conditions, (2) diluted slurry similarly to a pelagic analysis (Glud and Middelboe, 2004; Danovaro et al., 2008a; Corinaldesi et al., 2010) or by maintaining (3) intact Haps-cores of coastal sediments in water (Siem-Jørgensen et al., 2008). However, both the dilution-based and Würglerbag approaches (1 and 2) suffer from methodological biases altering either the heterotrophy activity and the mineralization rate, the host-virus contact and progeny of infections or the loss of viruses by exoprotease (Hansen et al., 2000; Danovaro et al., 2008b; Dell'Anno et al., 2009). Although, the dilutionbased technique is recommended by (Dell'Anno et al., 2009) as the most suitable methodology to estimate VP in marine systems, we chose to deduce VP directly in the field, during the emersion period, from net temporal variations in viral abundance as reflecting the true in situ production of surface sediment. By mimicking the mudflat in a low-tide situation, the microplate approach, is quite similar to the Würgler-bag method because it includes a homogenization step to uniformly distribute the undiluted mud into the wells. It reposes upon the same assumptions in terms of heterotrophic prokaryotes activity, biocide activity and competition with predators. Additionally, "Microplate incubation" is compatible with the use of Imagingfluorometers to simultaneously study photosynthesis. To our knowledge, this is the first time the Imaging-PAM (I-PAM) has been applied for the assessment of the effect of viral infection on the photosynthetic activity of mudflat MPB natural assemblages. As a non-destructive technique and a rapid assay, I-PAM greatly facilitates measurements on complex samples collected in situ and maintained ex situ and allows the accurate implementation of photosynthesis regulation kinetics.

\section{Are Benthic Viruses Mainly Prokaryotic Phages or Eukaryotic Viruses?}

Viral abundance in the mudflat of the MOB is within the range reported for marine sediments (from $10^{7}$ to $10^{11} \mathrm{ml}^{-1}$; Helton et al., 2006) and is even closer to the results reported for freshwater and shallow marine ecosystems $\left(9 \times 10^{9}\right.$ viruses $\mathrm{g}^{-1}$; Danovaro et al., 2008b). The viral abundance of mudflat sediments was 60 -fold higher than in the overlying water column. Such small ratios have been reported for other eutrophic bays: x22 for Moreton Bay (Hewson et al., 2001a), x14 for Niva Bay (Middelboe et al., 2003), and x10 for Chesapeake Bay (Helton et al., 2006) while higher values (from 100 to 1000) were observed in oligotrophic sites (Hewson et al., 2001a; Danovaro et al., $2008 \mathrm{~b}$ ). Because of a much higher abundance of prokaryotes in mudflat sediment, the virus to prokaryote ratio ranged $0.8-9.6$ like for Dutch intertidal sediment (0.6-1.4; Careira et al., 2015); benthic VPR was lower than previous observations in the MOB water column (11.6 \pm 3.7 in 2002-2003; Auguet et al., 2005). This general trend (except across the mouth of Chesapeake Bay; Drake et al., 1998) suggests a low viral production from prokaryotes in the sediments, even though the high density of prokaryotes and viruses probably fosters host-virus encounters (Filippini et al., 2006) which in turn may enhance prokaryotic resistance (Weinbauer et al., 2009). This situation is even more striking in that the higher availability of nutrients and organic matter in the sediment favors a higher activity of benthic heterotrophic prokaryotes (Danovaro and Serresi, 2000). This discrepancy could be explained by several factors that may be inferred from the virus-prokaryotes interaction: (i) different viral decay due to nuclease and/or protease concentrations (Middelboe et al., 2003; Filippini et al., 2006; Dell'Anno et al., 2015); (ii) a possible sorption on mineral matter or embedding in the EPS matrix, limiting the movement of bacteria and viruses and/or masking the viral receptors of bacterial cells (Danovaro and Serresi, 2000; Filippini et al., 2006), although polysaccharide depolymerases on viral capsids are known to degrade the EPS matrix (Sutherland et al., 2004); (iii) a hypothetical prevalence of lysogeny or chronic multiplication (Middelboe et al., 2003; Danovaro et al., 2008b); (iv) a reduction in the probability of virus-sensitive hosts encountering due to both high viral (Hewson and Fuhrman, 
2007; Helton and Wommack, 2009) and bacterial diversities (Torsvik et al., 2002); and (v) a direct influx of viruses from the water column which settle, or indirectly as a result of the settlement of lysogenic prokaryotes and/or cells visibly infected by lytic viruses (Hewson and Fuhrman, 2003; Taylor et al., 2003; Danovaro et al., 2008b; Pradeep Ram et al., 2009).

The autochthonous or allochthonous origin of benthic viruses is still a matter of debate. Some evidence supports an endogenous origin without excluding an input of pelagic viruses (Siem-Jørgensen et al., 2008). However, in the study case of the microphytobenthic (MPB) biofilm, the proportion of phytoviruses may be significant or even it may oversize the proportion of prokaryotic phages among the viriobenthos. The high abundance of viruses in the surface sediment without any sign of intensive viral infection of prokaryotes (low VPR) may thus originate (1) in the sorption of large particles, algal viruses, from the water column and/or (2) in the replication through benthic microalgae, all the more so since the burst-size of algal viruses (range $10^{2}-10^{4}$; Short, 2012) exceeds those of prokaryotes (range 3-69 in marine sediments; Danovaro et al., 2008b). Our results are congruent with both hypotheses. Indeed in the MOB intertidal mudflat, only $50 \%$ of viruses had a capsid size of less than $65 \mathrm{~nm}$ compared to $71 \%$ in the overlying water (Auguet et al., 2006). The sorption of viruses and the binding links on clay- and silt-particles enhances proportionally to the capsid-size (Dowd et al., 1998; Chattopadhyay and Puls, 1999). Moreover, large-sized virus particles may strongly counteract against the forces of desorption when the organic matter increases during emersion and the ionic strength decreases at rising tide (Gerba and Schaiberger, 1975). Overall, our results support the scenario of the replication of planktonic viruses through MPB diatoms since the addition of planktonic viruses $(\mathrm{Vp})$ only slightly changed the daily loss of benthic prokaryotes but significantly declined diatom microalgae biomass. This enhanced viral production at the expense of MPB diatoms, as a result of input of pelagic viruses, may suggest fluxes of viruses at the water-sediment interface via the MPB biofilm. Nevertheless, we clearly demonstrated the negative impact of benthic viruses on prokaryotes since changes in VP explained $79 \%$ of the changes in net prokaryotic growth, even though this was delayed compared to VP (power slope $=0.75$ ). This delay sustains the idea of a related viral replication through MPB hosts, in line with the relative high frequency of large capsid-sized virions while among the algal viruses isolated to date, virions size ranged from 22 to $>200 \mathrm{~nm}$ (Short, 2012).

\section{Viral Production and Prokaryotic Mortality}

The value of $10^{7}-10^{8}$ viruses produced $\mathrm{ml}^{-1} \mathrm{~h}^{-1}$ is in the range of $10^{6}-10^{9}$ viruses $\mathrm{g}^{-1} \mathrm{~h}^{-1}$ reported for marine sediments (Danovaro et al., 2008a; Corinaldesi et al., 2010). Like in the deep sea sediments of Sagami Bay (Middelboe et al., 2006), VP may be responsible in mudflat for an average of $29 \%$ of the net bacterial losses. Cell loss of $0.2-1.5 \%$ of the PSS and virusinduced mortality of $7-40 \%$ of prokaryotic production per hour, confirm the ascending gradient in viral-induced prokaryotic mortality in terms of production from coastal sediments (around 16\%, e.g., $12-57 \%$ in Adriatic Sea, Mei and Danovaro, 2004 and $4-41 \%$ in Central Øresund, Denmark, Siem-Jørgensen et al., 2008) to deep-sea sediments (89\%, Danovaro et al., 2008a) and positioned MOB mudflat in terms of viral impact on prokaryotic standing stock together with the sites with the lowest cell losses (0.3\%: Adriatic sea, Mei and Danovaro, 2004); 0.08-6.7\%: Central Øresund, Denmark (Glud and Middelboe, 2004; Siem-Jørgensen et al., 2008); <1\%: deep-sea sediments (Middelboe et al., 2006). The highest cell losses were reported in Southern California (414\%; Hewson and Fuhrman, 2003). Although, there was little apparent involvement of viruses in prokaryotic mortality, the net prokaryotic loss (the so-called prokaryotic net production) was positively related to the viral production rate in $\mathrm{MOB}$ during the emersion period. Differences in virus origin have been related to amplitude in prokaryotic responses; prokaryotes appeared more permissive to interstitial viruses (extracted from fresh sediment) than to surficial pelagic viruses. Benthic prokaryotes would mainly be of benthic origin and their viruses too. Our bioassays confirmed that after erosion into the overlying water, benthic bacteria and their viruses would be mainly located at the water interface and not dispersed efficiently upwards in the entire water column (Guizien et al., 2014).

\section{Impact of Viruses on the MPB Diatoms}

In MOB, MPB diatoms may be easily eroded from mudflat and $30-80 \%$ of diatoms of the water column can be from benthic origin depending of hydrodynamics (Guizien et al., 2014). Also there is a strong relationship between planktonic viruses and phytoplankton (Ory et al., 2010). Microalgae and especially diatoms have already been described as potential hosts for viral multiplication in the estuarine benthos and phytoplankton (Hewson et al., 2001b), and in monospecific cultures (planktonic diatoms, Nagasaki, 2008; Tomaru et al., 2012); benthic diatom Navicula sp. (Suttle et al., 1990). Thus, in MPB biofilm associated to surficial sediment, both prokaryotic, and algal viruses were logically present. Indeed for Chesapeake Bay benthic virome, $11 \%$ of the viral hits to dsDNA belonged to the Phycodnaviridae family (Helton and Wommack, 2009).

As a consequence, the impact of viruses on MPB is more complex than on prokaryotes, due to higher dispersion of diatoms in the entire water column. Planktonic viruses like benthic viruses may regulate diversity and photosynthetic activity of the MPB. In our experiments, during the first days of infection, $\mathrm{Vb}$ modified the abundance of MPB diatoms by promoting the growth of Navicula sp. while inhibiting the growth of the P$\mathrm{G}$ taxon, the two dominant taxa. In contrast, Vp decreased the abundance of both taxa, with a greater impact on the P-G taxon, which thus appeared to be more sensitive to viral infection (by both $\mathrm{Vb}$ and $\mathrm{Vp}$ ) than Navicula sp.. This observation is congruent with the diatom species specificity of viruses (Nagasaki et al., 2005) and may infer a selective growth inhibition of a subset of the microalgal community (Castberg et al., 2001; Hewson et al., 2001b; Larsen et al., 2004). Some microbial/diatom species may then benefit from the subsequent lower competition for light and nutrients.

Before the lysis of cells, the selective decline of a community or a population is probably linked to the negative effect of viral infection on photosynthetic activity, as reported before for 
phytoplankton (Suttle, 1992; Hewson et al., 2001b; Juneau et al., 2003). Indeed, both $\mathrm{Vb}$ and $\mathrm{Vp}$ infection of MPB decreased its photosynthetic efficiency $\left(F_{v} / F_{m}\right)$. Additionally, $\mathrm{Vb}$ infection specifically decreased and slowed down the development of the photoprotective NPQ; this is in contrast to the effect of $\mathrm{Vp}$ infection in the bloom-forming raphidophyte Heterosigma akashiwo (Juneau et al., 2003). Interestingly, light intensity and UVB radiation are important factors controlling algal host-virus interactions (Jacquet and Bratbak, 2003; Baudoux and Brussaard, 2008). This is even more significant since it is well documented that the diatom and MPB communities have a powerful NPQ and that in reaction to a decrease in NPQ, MPB photosynthesis and behavior are impaired (Laviale et al., 2015). The decrease in NPQ could render the cells more sensitive to environmental stresses, i.e., high light, temperature and salinity stresses (Juneau et al., 2015; Laviale et al., 2015). Forehand for virus-infected plant models, NPQ may be a relevant "disease signature" to diagnose the different stages of infection, increasing locally at the early stage of viral infection and decreasing at the final stage in senescent tissue (Pérez-Bueno et al., 2006; Pérez-Clemente et al., 2015). Further, studies will be useful to extrapolate the virus biotic effect on NPQ to photosynthetic protists.

In this context, $\mathrm{Vp}$ generated the highest Viral Production (VP) together with the highest impact on MPB biomass and photosynthesis but had no effect on NPQ. Despite the reduction in photosynthetic potential, the maintenance of photoprotection may support the permissiveness of cells (or sub-sets of cells) by offering a sufficient energy level for viral replication (Juneau et al., 2003; Baudoux and Brussaard, 2008). In contrast, the viral yield during $\mathrm{Vb}$ infection may be limited by the decrease in the photoprotection capacity of MPB. These observations support the hypothesis of Baudoux and Brussaard (2008) that diatom species-specific photo-acclimation/-protection capacity (defined according to their habitat of origin, Barnett et al., 2015) may determine the differential effect of irradiance on viral propagation by influencing the burst size and/or the latent period. Overall, efficient Vp infection of MPB questions the real susceptibility of MPB diatoms to viruses in the sediment and in the water column due to their upward sediment-water transport at high-tide (i.e., resuspension in the water column) and their downward water-sediment transports when settling.

\section{Ecological Implications}

The MPB biofilm of intertidal mudflats is a product of complex interactions between microalgal primary producers, bacteria and viruses. The specific algae-prokaryotes coupling, as well as the structure of the prokaryotic community and its remineralisation activity (Glud and Middelboe, 2004; Haynes et al., 2007; Danovaro et al., 2008b) have been related to (i) the availability of labile organic matter derived from detritus (Galois et al., 2000), (ii) the cell-derived EPS production (Haynes et al., 2007; Bruckner et al., 2011), and (iii) the virus-mediated production of DOM as cellular debris and decomposed virions (Wilhelm and Suttle, 1999; Sutherland et al., 2004; Dell'Anno et al., 2015).

Pore-water content would be one of the main factors determining the encounter rate between viruses and hosts (Weinbauer et al., 2009). For the MOB mudflat, as in soil
(Srinivasiah et al., 2008), water content (WC) was inversely correlated with the Virus to Prokaryote Ratio while Pinto et al. (2013) reported a positive relationship from global analysis of worldwide in situ data and WC was positively related to prokaryotes abundance. Nonetheless at the emersion-scale, the VPR always varied inversely to net bacterial growth, from negative to positive values, since a net viral production occurred during emersion concomitantly to the decrease in water content and in line with the negative links between porosity and VP (Pinto et al., 2013) and viral abundance (Helton et al., 2006). No change of the VPR over emersion occurred when the net prokaryotic increase was around $20 \%$ of PSS. Interestingly, we observed such similar features in the dynamics of the viruses and prokaryotes, at spring tide on July 21 of 2008 (outer data on Figure 6). This was a singular day characterized by a minimum value of Chl $a$ biomass and a high erodibility, which may be partially explained by the destabilizing effect of a more pronounced hygroscopic feature of EPS (see for details, Orvain et al., 2014b). Therefore, the occurrence of area of water retention and the breaks of cell-matrix bonds may corollary favor in fine the bacterial growth. However taking into account the viral dynamics and the VPR allows us to also postulate that phytophages may be responsible of the observed decline of MPB on July 21 supporting indirectly the bacterial growth. To round off this item, VPR may be a good integrative proxy for the description of the functioning of the microbial food-web within a complex biofilm. It reflects both the interactions between the different microbial components (virus, prokaryotes, $\mathrm{MPB}$ ), and their respective and interlinked relationships with water content and the bioavailability of organic matter but also its hydrophobicity (notably the protein/polysaccharide ratio of EPS).

Like in water column where viral abundance is influenced by the quality, size and age of the aggregates (Weinbauer et al., 2009), it may be related, in the case of intertidal mudflat, to the maturation and the structure of MPB biofilm, which is seasonally distinguishable by differences in the bioavailability of the organic matter (as detailed in Orvain et al., 2014a). Briefly, DOM was higher in the developing biofilm of July 2008 and its composition may traduce a synergetic collaboration between highly active diatoms and prokaryotic cells in the resistance to strong irradiance and salinities whereas the algal biomass and prokaryotic abundance standing stock were less abundant than in the more stabilized biofilm. In winter 2008, diatoms excreted bound EPS carbohydrate enriched in rhamnose that can promote the biostabilization of the sediment and act as bacterial development sensor (Pierre et al., 2012; Orvain et al., 2014a). Moreover, the dense population of the snail Peringia ulvae in summer may also infer seasonal differences in microbes abundance due to grazing activity (Orvain et al., 2014b) and/or vertical bioturbation of sediment (as proposed for subpolar ecosystem, Wróbel et al., 2013). Nevertheless, we can postulate that, during the ingrowing of biofilm (July), the viral production was enhanced since both microalgae and prokaryotes were metabolically active (prokaryotic $\mathrm{P} / \mathrm{B}=3.84$ ) without allowing, nevertheless, an efficient viral turn over. On contrary, when the MPB biofilm was better structured (February) but less active (prokaryotic $\mathrm{P} / \mathrm{B}=3.21$ ), the prokaryotes and the microalgae 
grew under steady-state conditions in phase with a lower but more efficient viral production to maintain the viral stock.

Overall, this study credited the previously report of seasonal variation of the benthic viral shunt and the estimated supplies for Prokaryotic Carbon Demand (PCD), i.e., 2 and 12\% of $\mathrm{PCD}$, in winter and summer respectively, considering all viruses as prokaryotic phages (to be compared to $0.1-10 \%$ of PCD; Pinto et al., 2013). Therefore, the impact of viruses may appear negligible for nutrition of heterotrophic prokaryotes in surface sediment worldwide compared to deeper anoxic sediment (30\%, Danovaro et al., 2008a).

\section{CONCLUDING REMARKS}

Mudflat viriobenthos is a highly active component of the MPB biofilm during emersion. Viral infections play an important role in the functioning of the surficial sediment of intertidal mudflat with a seasonal variability in the viral mediated mortality of prokaryotes. However, a sizeable part of benthic viruses (and probably of pelagic viruses) originates from MPB and may regulate biomass and diversity of the benthic diatoms/microalgae. Therefore, viruses must be included to current models of the functioning of the benthos-pelagos coupled food-web of intertidal mudflats not only as bacteriophages (Saint-Béat et al., 2014) but also as phytophages albeit the partitioning between the phages of MPB and prokaryotes remains to circumscribe, as well as the exact impact of benthic and planktonic viruses on MPB and phytoplankton biomasses.

\section{REFERENCES}

Auguet, J. C., Montanié, H., Delmas, D., Hartmann, H. J., and Huet, V. (2005). Dynamic of virioplankton abundance and its environmental control in the Charente Estuary (France). Microb. Ecol. 50, 337-349. doi: 10.1007/s00248-0050183-2

Auguet, J. C., Montanié, H., and Lebaron, P. (2006). Structure of Virioplankton in the Charente Estuary (France): transmission electron microscopy versus pulsed field gel electrophoresis. Microb. Ecol. 51, 197-208. doi: 10.1007/s00248-0050043-0

Barnett, A., Méléder, V., Blommaert, L., Lepetit, B., Gaudin, P., Vyverman, W., et al. (2015). Growth form defines physiological photoprotective capacity in intertidal benthic diatoms. ISME J. 9, 32-45. doi: 10.1038/ismej. 2014.105

Baudoux, A.-C., and Brussaard, C. P. (2008). Influence of irradiance on virus-algal host interactions. J. Phycol. 44, 902-908. doi: 10.1111/j.1529-8817.2008.00543.x

Blanchard, G. F., Sauriau, P. G., Cariou-Le Gall, V., Gouleau, D., Garet, M. J., and Olivier, F. (1997). Kinetics of tidal resuspension of microbiota: testing the effetcs of sediment cohesiveness and bioturbation using flume experiments. Mar. Ecol. Progr. Ser. 151, 17-25. doi: 10.3354/meps151017

Bruckner, C. G., Rehm, C., Grossart, H.-P., and Kroth, P. G. (2011). Growth and release of extracellular organic compounds by benthic diatoms depend on interactions with bacteria. Environ. Microbiol. 13, 1052-1063. doi: 101111/j. 1462-2920.2010.02411.x

Brussaard, C. P. D., Payet, J. P., Winter, C., and Weinbauer, M. G. (2010). "Quantification of aquatic viruses by flow cytometry," in Manual of Aquatic Viral Ecology, eds S. W. Wilhelm, M. G. Weinbauer, and C. A. Suttle (Waco, TX: ASLO), 102-109.

Careira, C., Staal, M., Middelboe, M., and Brussaard, C. P. D. (2015). Counting viruses and bacteria in photosynthetic microbial mats. Appl. Environ. Microbiol. 81, 2149-2155. doi: 10.1128/AEM.02863-14

\section{ACKNOWLEDGMENTS}

This work was partly supported by the French National Research Program PEVS (2000-2006) and is part of the VASIREMI project (2007-2011) funded by the French National Research Agency (ANR-06-BLAN-0393-01). HM designed the different bioassays, analyzed and conceptualized results. JL performed and analyzed the photosynthetic measurements on microalgae, he was supported by the CNRS and the French national consortium CPER "Littoral" (2007-2013), including European FEDER funds. MC, supported by a Ph.D. fellowship from the French National Institute for Scientific Research (CNRS) and the "Poitou-Charentes" Region, was in charge of sediment sampling and counts of prokaryotes in February and July 2008. We thank Christine Dupuy for her coordination of the VASIREMI program, M. Bréret for chlorophyll $a$ and DOM analysis, and C. Fontaine and six undergraduate students (A. Tchechenko, G. Chereau, E. Goutanier, J. Meilland, P. Pelard, and J. Ezzedine) for their help in microbial counting. This paper is a contribution to the "biofilm" work package of the LIENSs research unit. We thank the reviewers for their comments on the manuscript.

\section{SUPPLEMENTARY MATERIAL}

The Supplementary Material for this article can be found online at: http://journal.frontiersin.org/article/10.3389/fmicb. 2015.01214

Castberg, T., Larsen, A., Sandaa, R. A., Brussaard, C. P. D., Egge, J. K., Heldal, M., et al. (2001). Microbial population dynamics and diversity during a bloom of the marine coccolithophorid Emiliania huxleyi (Haptophyta). Mar. Ecol. Prog. Ser. 221, 39-46. doi: 10.3354/meps221039

Chattopadhyay, S., and Puls, R. (1999). Adsorption of bacteriophages on clay minerals. Environ. Sci. Technol. 33, 3609-3614. doi: 10.1021/es9811492

Corinaldesi, C., Dell'Anno, A., Magagnini, M., and Danovaro, R. (2010). Viral decay and viral production rates in continental-shelf and deep-sea sediments of the Mediterranean Sea. FEMS Microbial. Ecol. 72, 208-218. doi: 10.1111/j.15746941.2010.00840.x

Danovaro, R., Corinaldesi, C., Filippini, M., Fischer, U. R., Gessner, M. O., Jacquet, S., et al. (2008b). Viriobenthos in freshwater and marine sediments: a review. Freshw. Biol. 53, 1186-1213. doi: 10.1111/j.1365-2427.2008.01961.x

Danovaro, R., Dell'Anno, A., Corinaldesi, C., Magagnini, M., Noble, R., Tamburini, C., et al. (2008a). Major viral impact on the functioning of benthic deep-sea ecosystems. Nature 454, 1084-1087. doi: 10.1038/nature07268

Danovaro, R., Dell'Anno, A., Serresi, M., and Vanucci, S. (2001). Determination of virus abundance in marine sediments. Appl. Environ. Microbiol. 67, 1384-1387. doi: 10.1128/AEM.67.3.1384-1387.2001

Danovaro, R., and Middelboe, M. (2010). "Separation of free particles from sediments in aquatic systems," in Manual of Aquatic Viral Ecology, eds S. W. Wilhelm, M. G. Weinbauer, and C. A. Suttle (Waco, TX: ASLO), 74-81.

Danovaro, R., and Serresi, M. (2000). Viral density and virus-to-bacterium ratio in deep-sea sediments of the eastern mediterranean. Appl. Environ. Microbiol. 66, 1857-1861. doi: 10.1128/AEM.66.5.1857-1861.2000

Dell'Anno, A., Corinadelsi, C., and Danovaro, R. (2015). Virus decomposition provides an important contribution to benthic deep-sea ecosystem functioning. Proc. Natl. Acad. Sci. U.S.A. 112, E2014-E2019. doi: 10.1073/pnas.1422234112

Dell'Anno, A., Corinaldesi, C., Magagnini, M., and Danovaro, R. (2009). Determination of viral production in aquatic sediments using the dilutionbased approach. Nat. Protocols 4, 1013-1022. doi: 10.1038/nprot.2009.82 
Dowd, S. E., Pillai, S. D., Wang, S., and Corapcioglu, M. Y. (1998). Delineating the specific influence of virus isolelectric point and size on virus adsorption and transport through sandy soils. Appl. Environ. Microbiol. 64, 405-410.

Drake, L. A., Choi, K.-H., Haskell, A. G. E., and Dobbs, F. C. (1998). Vertical profiles of virus-like particles and bacteria in the water column and sediments of Chesapeake Bay, U. S. A. Aquat. Microbial. Ecol. 16, 17-25.

Duhamel, S., and Jacquet, S. (2006). Flow cytometric analysis of bacteria and virus-like particles in lake sediments. J. Microbiol. Meth. 64, 316-332. doi: 10.1016/j.mimet.2005.05.008

Filippini, M., Buesing, N., Bettarel, Y., Sime-Ngando, T., and Gessner, M. O. (2006). Infection paradox: high abundance but low impact of freshwater benthic viruses. Appl. Environ. Microbiol. 72, 4893-4898. doi: 10.1128/aem.00319-06

Fuhrman, J. A. (1999). Marine viruses and their biogeochemical and ecological effects. Nature 399, 541-548. doi: 10.1038/21119

Galois, R., Blanchard, G. F., Seguignes, M., Huet, V., and Joassard, L. (2000). Spatial distribution of sediment particulate organic matter on two estuarine intertidal mudflats: a comparison between Marenns-Oléron Bay (France) and the Humber Estuary (UK). Cont. Shelf Res. 20, 1199-1217. doi: 10.1016/S02784343(00)00019-4

Gastrich, M. D., Leigh-Bell, J. A., Gobler, C. J., Anderson, O. R., Wilhelm, S. W., and Bryan, M. (2004). Viruses as potential regulators of regional brown tide blooms caused by the alga, Aureococcus anophagefferens. Estuaries 27, 112-119. doi: $10.1007 / \mathrm{BF} 02803565$

Gerba, C. P. (1984). Applied and theoretical aspects of virus adsorption to surfaces. Adv. Appl. Microbiol. 30, 133-168. doi: 10.1016/S0065-2164(08)70054-6

Gerba, C. P., and Schaiberger, G. (1975). Effect of particulates on virus survival in seawater. J. Water Pollut. Control Fed. 47, 93-103.

Glud, R., and Middelboe, M. (2004). Virus and bacteria dynamics of a costal sediment: implication for benthic carbon cycling. Limnol. Oceanogr. 49, 2073-2081. doi: 10.4319/lo.2004.49.6.2073

Guizien, K., Dupuy, C., Ory, P., Montanié, H., Hartmann, H., Chatelain, M., et al. (2014). Microorganism dynamics during a rising tide: disentangling effects of resuspension and mixing with offshore waters above an intertidal mudflat. J. Mar. Syst. 129, 178-188. doi: 10.1016/j.jmarsys.2013.05.010

Gutierrez, L., and Nguyen, T. H. (2012). Interactions between Rotavirus and Suwannee River Organic Matter: aggregation, deposition, and adhesion force measurement. Environ. Sci. Technol. 46, 8705-8713. doi: 10.1021/ es301336u

Hansen, J. W., Thamdrup, B., and Jørgensen, B. B. (2000). Anoxic incubation of sediment in gas-tight plastic bags: a method for biogeochimical process studies. Mar. Ecol. Progr. Ser. 208, 243-282. doi: 10.3354/meps 208273

Haynes, K., Hofmann, T., Smith, C., Ball, A., Underwood, G., and Osborn, A. (2007). Diatom-derives carbohydrates as factors affecting bacterial community composition in estuarine sediments. Appl. Environ. Microbiol. 73, 6112-6124. doi: 10.1128/AEM.00551-07

Helton, R., Liu, L., and Wommack, K. (2006). Assessment of factors influencing direct enumeration of viruses within estuarine sediments. Appl. Environ. Microbiol. 72, 4767-4774. doi: 10.1128/AEM.00297-06

Helton, R. R., Wang, K., Kan, J., Powell, D. H., and Wommack, K. E. (2012). Interannual dynamics of viriobenthos abundance and morphological diversity in Chesapeake Bay sediments. FEMS Microbiol. Ecol. 79, 474-486. doi: 10.1111/j.1574-6941.2011.01238.x

Helton, R., and Wommack, K. (2009). Seasonal dynamics and metagenomic characterization of estuarine viriobenthos assemblages by ramdomly amplified polymorphic DNA PCR. Appl. Environ. Microbiol. 75, 2259-2265. doi: 10.1128/AEM.02551-08

Hewson, I., Barbosa, J. G., Brown, J. M., Donelan, R. P., Eaglesham, J. B., et al. (2012). Temporal dynamics and decay of putatively allochthonous and autochthonous viral genotypes in contrasting freshwater lakes. Appl. Environ. Microbiol. 78, 6583-6591. doi: 10.1128/AEM.01705-12

Hewson, I., and Fuhrman, J. A. (2003). Viriobenthos production and virioplankton sorptive scavenging by suspended sediment particles in coastal and pelagic waters. Microb. Ecol. 46, 337-347. doi: 10.1007/s00248-002-1041-0

Hewson, I., and Fuhrman, J. A. (2007). Covariation of viral parameters with bacterial assemblage richness and diversity in the water column and sediments. Deep Sea Res. I 54, 811-830. doi: 10.1016/j.dsr.2007.02.003

Hewson, I., O’Neil, J. M., Fuhrman, J. A., and Dennison, W. C. (2001a). Virus-like particle distribution and abundance in sediments and overlying waters along eutrophication gradients in two subtropical estuaries. Limnol. Oceanogr. 46, 1734-1746. doi: 10.4319/lo.2001.46.7.1734

Hewson, I., O’Neil, J. M., Heil, C. A., Bratbak, G., and Dennison, W. C. (2001b). Effects of concentrated viral communities on photosynthesis and community composition of co-occurring benthic microalgae and phytoplankton. Aquat. Microb. Ecol. 25, 1-10. doi: 10.3354/ame025001

Hurwitz, L., Hallam, S. J., and Sullivan, M. B. (2013). Metabolic reprogramming by viruses in the sunlit and dark ocean. Genome Biol. 14:R123. doi: 10.1186/gb2013-14-11-r123

Jacquet, S., and Bratbak, G. (2003). Ultraviolet radiation on marine virusphytoplankton interactions. FEMS Microbial. Ecol. 44, 279-289. doi: 10.1016/S0168-6496(03)00075-8

Juneau, P., Barnett, A., Méléder, V., Dupuy, C., and Lavaud, J. (2015). Combined effect of high light and high salinity on the regulation of photosynthesis in three diatom species belonging to the main growth forms of intertidal flat inhabiting microphytobenthos. J. Exp. Mar. Biol. Ecol. 463, 95-104. doi: 10.1016/j.jembe.2014.11.003

Juneau, P., Lawrence, J., Suttle, C. A., and Harrison, P. J. (2003). Effetcs of viral infection on photosynthetic processes in the bloom-forming alga Heterosigma akashiwo. Aquat. Microb. Ecol. 31, 9-17. doi: 10.3354/ame031009

Larsen, A., Fonnes, G. A., Sandaa, R. A., Castberg, T., Thyrhaug, R., Erga, S., et al. (2004). Spring phytoplnkton bloom dynamics in Norvegian coastal waters: microbial community succession and diversity. Limnol. Oceanogr. 49, 180-190. doi: 10.4319/lo.2004.49.1.0180

Laviale, M., Barnett, A., Ezequiel, J., Lepetit, B., Frankenbach, S., Méléder, V., et al. (2015). Response of intertidal benthic microalgal biofilms to a coupled lighttemperature stress: evidence for latitudinal adaptation along the Atlantic coast of Southern Europe. Environ. Microbiol. 10, 3662-3677. doi: 10.1111/14622920.12728

Lucas, F., Meziane, T., Bertru, G., and Retière, C. (1996). Bacteria of sediments: extraction and distribution in a macrotidal mudflat (Bay of Saint-Michel). C. $R$. Acad. Sci. Paris Ser. III 319, 537-542.

Luef, B., Luef, F., and Peduzzi, P. (2009). Online program "Vipcal" for calculating lytic viral production and lysogenic cells based on a viral reduction approach. Environ. Microbiol. Rep. 1, 78-85. doi: 10.1111/j.1758-2229.2008.00008.x

Lunau, M., Lemke, A., Walther, K., Martens-Habbena, W., and Simon, M. (2005). An improved method for counting bacteria from sediments and turbid environments by epifluorescence microscopy. Environ. Microbiol. 7, 961-968. doi: 10.1111/j.1462-2920.2005.00767.x

Mei, M. L., and Danovaro, R. (2004). Virus production and life strategies in aquatic sediments. Limnol. Oceanogr. 49, 459-470. doi: 10.4319/lo.2004.49.2.0459

Middelboe, M., Glud, R., and Finster, K. (2003). Distribution of viruses and bacteria in relation to diagenetic activity in an estuarine sediment. Limnol. Oceanogr. 48, 1447-1446. doi: 10.4319/lo.2003.48.4.1447

Middelboe, M., Glud, R. N., and Filippini, M. (2011). Viral abundance and activity in the deep sub-seafloor biosphere. Aquat. Microb. Ecol. 63, 1-8. doi: 10.3354/ame01485

Middelboe, M., Glud, R., Wenzhöfer, F., Oguri, K., and Kitazato, H. (2006). Spatial distribution and activity of viruses in the deep-sea sediments of Sagami Bay, Japan. Deep Sea Res. I 53, 1-13. doi: 10.1016/j.dsr.2005.09.008

Montanié, H., Hartmann, H. J., Crottereau, C., and Trichet, C. (2002). Virus like particle analysis in a seston-rich coastal pond using transmission electron microscopy. Aquat. Microb. Ecol. 28, 105-115. doi: 10.3354/ ame028105

Montanié, H., Ory, P., Orvain, F., Delmas, D., Dupuy, C., and Hartmann, H. J. (2014). Microbial interactions in marine water amended by eroded benthic biofilm: a case study from an intertidal mudflat. J. Sea Res. 92, 74-85. doi: 10.1016/j.seares.2013.11.011

Nagasaki, K. (2008). Dinoflagellates, diatoms, and their viruses. J. Microbiol. 46, 235-243. doi: 10.1007/s12275-008-0098-y

Nagasaki, K., Tomaru, Y., Takao, Y., Nishida, K., Shirai, Y., Suzuki, H., et al. (2005). Previously unknown virus infects marine diatoms. Appl. Environ. Microbiol. 71, 3528-3535. doi: 10.1128/AEM.71.7.3528-3535.2005

Noble, R. T., and Fuhrman, J. A. (1998). Use of SYBR Green I for rapid epifluorescence counts of marine viruses and bacteria. Aquat. Microb. Ecol. 14, 113-118. doi: 10.3354/ame014113

Orvain, F., de Crignis, M., Guizien, K., Lefèvre, S., Mallet, C., Takahashi, E., et al. (2014a). Tidal and seasonal effects on the short-term temporal patterns of 
bacteria, microphytobenthos and exopolymers in natural intertidal biofilms (Brouage, France). J. Sea Res. 92, 6-18. doi: 10.1016/j.seares.2014.02.018

Orvain, F., Guizien, K., Lefebvre, S., Bréret, M., and Dupuy, C. (2014b). Relevance of macrozoobenthic grazers to understand the dynamic behaviour of sediment erodibility and microphytobenthos resuspension in sunny summer conditions. J. Sea. Res. 92, 46-55. doi: 10.1016/j.seares.2014.03.004

Ory, P., Hartmann, H. J., Jude, F., Dupuy, C., Del Amo, Y., Catala, P., et al. (2010). Pelagic food web patterns: do they modulate virus and nanoflagellate effetcs on picoplankton during the phytoplankton spring bloom? Environ. Microbiol. 12, 2755-2772. doi: 10.1111/j.1462-2920.2010.02243.x

Pascal, P.-Y., Dupuy, C., Richard, P., Mallet, C., Armynot du Châtelet, E., and Niquil, N. (2009). Seasonal variation in consumption of benthic bacteria by meio-and macrofauna in an intertidal mudflat. Limnol. Oceanogr. 54, 1048-1059. doi: 10.4319/lo.2009.54.4.1048

Pérez-Bueno, M. L., Ciscato, M., van de Ven, M., García-Luque, I., Valcke, R., and Barón, M. (2006). Imaging viral infection: studies on Nicotiana benthamiana plants infected with the pepper mild mottle tobamovirus. Photosynth. Res. 90, 111-123. doi: 10.1007/s11120-006-9098-0

Pérez-Clemente, R. M., Montoliu, A., Vives, V., López-Climent, M. F., and GómezCadenas, A. (2015). Photosynthetic and antioxydant responses of Mexican lime (Citrus aurantifolia) plants to Citrus tristeza virus infection. Plant Pathol. 64, 16-24. doi: 10.1111/ppa.12241

Perkins, R., Kromkamp, J., Serôdio, J., Lavaud, J., Jesus, B., Mouget, J., et al. (2010). "The application of variable chlorophyll fluorescence to microphytobenthic biofilms," in Chlorophyll a Fluorescence in Aquatic Sciences: Methods and Applications. Developments in Applied Phycology 4, eds D. J. Suggett, O. Prasil, and M. A. Borowitzka (Dordrecht: Springer Science), 237-275.

Pierre, G., Graber, M., Alibay Rafiliposon, B., Dupuy, C., Orvain, F., De Crignis, M., et al. (2012). Biochemical composition and changes of extracellular polysaccharides (ECPS) produced during microphytobenthic biofilm development (Marennes-Oléron, France). Microb. Ecol. 63, 157-169. doi: 10.1007/s00248-011-9959-8

Pinto, F., Larsen, S., and Casper, P. (2013). Viriobenthos in aquatic sediments: varia bility in abundance and production and impact on the C-cycle. Aquat. Sci. 75, 571-579. doi: 10.1007/s00027-013-0301-z

Porter, K., and Feig, Y. (1980). The use of DAPI for identifying and counting aquatic microflora. Limnol. Oceanogr. 25, 943-948. doi: 10.4319/lo.1980.25. 5.0943

Pradeep Ram, A., Sabart, M., Latour, D., and Sime-Ngando, T. (2009). Low effect of viruses on bacteria in deep anoxic water and sediment of a productive frahwater reservoir. Aquat. Microb. Ecol. 55, 255-265. doi: 10.3354/ame01300

Ralph, P., Wilhelm, C., Lavaud, J., Jakob, T., Petrou, K., and Kranz, S. (2010). "Fluorescence as an assay to understand aspects of the physiology of light regulation," in Chlorophyll a Fluorescence in Aquatic Sciences: Methods and Applications, Series: Developments in Applied Phycology, Vol. 4, eds D. Sugget, O. Prasil, and M. A. Borowitzka (Dordrecht: Springer), 75-89.

Saint-Béat, B., Dupuy, C., Bocher, P., Chalumeau, J., and de Crignis, M., Fontaine, C., et al. (2013). Key features of intertidal webs that support migratory shorebirds. PLoS ONE 8:e76739. doi: 10.1371/journal.pone.0076739

Saint-Béat, B., Dupuy, C., Agogué, H., Carpentier, A., Chalumeau, J., Como, S. et al. (2014). How the resuspension of the biofilm alter the functionning of the benthos-pelagos couled food-web of a bare mudflat in MarennesOléron Bay (NE Atlantioc)? J. Sea Res. 92, 144-157. doi: 10.1016/j.seares.2014. 02.003

Short, S. M. (2012). The ecology of viruses that infect eukaryotic algae. Environ. Microbiol. 14, 2253-2271. doi: 10.1111/j.1462-2920.2012.02706.x

Siem-Jørgensen, M., Glud, R. N., and Middelboe, M. (2008). Viral deynamics in a coastal sediments: seasonal pattern, controlling factors and relations to the pelagic-benthic coupling. Mar. Biol. Res. 4, 165-179. doi: 10.1080/17451000 801888718

Sime-Ngando, T. (2014). Environmental bacteriophages: viruses of microbes in aquatic ecosystems. Front. Microbiol. 5:355. doi: 10.3389/fmicb.2014.00355

Srinivasiah, S., Bhavsar, J., Thapar, J., Liles, M., Schoenfeld, T., and Wommack, K. (2008). Phages across the biosphère: contrasts of viruses in soil and aquatic environments. Res. Microbiol. 159, 349-357. doi: 10.1016/j.resmic.2008.04.010
Sutherland, I., Hughes, K., Skillman, L., and Tait, K. (2004). The interactions of phage and biofilms. FEMS Microb. Lett. 232, 1-6. doi: 10.1016/S03781097(04)00041-2

Suttle, C. (1992). Inhibition of photosynthesis in phytoplankton by the submicron size fraction concentrated from seawater. Mar. Ecol. Prog. Ser. 87, 105-112. doi: 10.3354/meps087105

Suttle, C. A. (2007). Marine viruses - major players in the global ecosystem. Nat. Rev. Microbiol. 5, 801-812. doi: 10.1038/nrmicro1750

Suttle, C., Chan, A., and Cotrell, M. (1990). Infection of Phytoplancton by viruses and reduction of primary productivity. Nature 347, 467-469. doi: $10.1038 / 347467 \mathrm{a} 0$

Taylor, G. T., Hein, C., and Iabichella, M. (2003). Temporal variations in viral distributions in the anoxic Cariaco Basin. Aquat. Microb. Ecol. 30, 103-116. doi: $10.3354 / \mathrm{ame} 030103$

Thingstad, F., and Lignell (1997). Theoretical models for the control of the bacterial growth rate, abundance, diversity and carbon demand. Aquat. Microb. Ecol. 13, 19-27. doi: 10.3354/ame013019

Tomaru, Y., Toyoda, K., Kimura, K., Hata, N., Yoshida, M., and Nagasaki, K. (2012). First evidence for the existence of pennate diatom viruses. ISME J. 6, 1445-1448. doi: 10.1038/ismej.2011.207

Torsvik, V., Ovreas, L., and Thingstad, T. F. (2002). Prokaryotic diversity Magnitude, dynamics, and controlling factors. Science 296, 1064-1066. doi: $10.1126 /$ science. 1071698

Walshe, G. E., Pang, L., Flury, M., Close, M. E., and Flintoft, M. (2010). Effects of $\mathrm{pH}$, ionic strength, dissolved organic matter, and flow rate on the co-transport of MS2 bacteriophages with kaolinite in gravel aquifer media. Water Res. 44, 1255-1269. doi: 10.1016/j.watres.2009.11.034

Weinbauer, M. (2004). Ecology of prokaryotic viruses. FEMS Microbiol. Rev. 28, 127-181. doi: 10.1016/j.femsre.2003.08.001

Weinbauer, M., Bettarel, Y., Cattaneo, R., Luef, B., Maier, C., and Motegi, C. (2009). Viral ecology of organic and inorganic particles in aquatic systems: avenues for further research. Aquat. Microb. Ecol. 57, 321-341. doi: 10.3354/ame01363

Weinbauer, M., Rowe, J., and Wilhelm, S. W. (2010). "Determining rates of virus production in aquatic systems by the virus reduction approach," in Manual of Aquatic Viral Ecology, eds S. W. Wilhelm, M. G. Weinbauer, and C. A. Suttle (Waco, TX: ASLO), 1-8.

Wen, K., Ortmann, A. C., and Suttle, C. A. (2004). Accurate estimation of viral abundance by epifluorescence microscopy. Appl. Environ. Microbiol. 70, 3862-3867. doi: 10.1128/AEM.70.7.3862-3867.2004

Wilhelm, S. W., and Suttle, C. A. (1999). Viruses and nutrient cycles in the sea. Bioscience 49, 781-788. doi: 10.2307/1313569

Winter, C., Bouvier, T., Weinbauer, M., and Thingstad, F. (2010). Trade-offs between competition and defense specialists among unicellular planktonic organisms: the "killing the winner" hypothesis revisited. Microbiol. Mol. Biol. R. 74, 42-57. doi: $10.1128 / \mathrm{mmbr} .00034-09$

Wong, K., Voice, T. C., and Xagoraraki, I. (2013). Effect of organic carbon on sorption of human adenovirus to soil particles and laboratory containers. Water Res. 47, 3339-3346. doi: 10.1016/j.watres.2013.03.029

Wróbel, B., Filippini, M., Piwowarczyk, J., Kêdra, M., Kuliñ, K., and Middelboe, M. (2013). Low virus to prokaryote ratios in the cold: benthic viruses and prokaryotes in a subpolar marine ecosystem (Hornsund, Svalbard). Int. Microbiol. 16, 45-52. doi: 10.2436/20.1501.01.179

Zhao, W., Walker, S. L., Huang, Q., and Cai, P. (2014). Adhesion of bacterial pathogens to soil colloidal particles: influences of cell type, natural organic matter, and solution chemistry. Water Res. 53, 35-46. doi: 10.1016/j.watres.2014.01.009

Conflict of Interest Statement: The authors declare that the research was conducted in the absence of any commercial or financial relationships that could be construed as a potential conflict of interest.

Copyright (C) 2015 Montanié, De Crignis and Lavaud. This is an open-access article distributed under the terms of the Creative Commons Attribution License (CC BY). The use, distribution or reproduction in other forums is permitted, provided the original author(s) or licensor are credited and that the original publication in this journal is cited, in accordance with accepted academic practice. No use, distribution or reproduction is permitted which does not comply with these terms. 